FY 2006

\title{
FRACTIONAL-SLOT SURFACE MOUNTED PM MOTORS WITH CONCENTRATED WINDINGS FOR HEV TRACTION DRIVES
}

Prepared by:

Oak Ridge National Laboratory

Mitch Olszewski, Program Manager

Submitted to:

Energy Efficiency and Renewable Energy

FreedomCAR and Vehicle Technologies

Vehicle Systems Team

Susan A. Rogers, Technology Development Manager

October 2005 
NATIONAL LABORATORY

MANAGED BY UT-BATTELLE

FOR THE DEPARTMENT OF ENERGY

\section{Engineering Science \& Technology Division}

\section{Fractional-Slot Surface Mounted PM Motors with Concentrated Windings for HEV Traction Drives}

J. M. Bailey

J. W. McKeever
Prepared by the

OAK RIDGE NATIONAL LABORATORY

Oak Ridge, Tennessee 37831

managed by

UT-BATTELLE, LLC

for the

U.S. DEPARTMENT OF ENERGY

Under contract DE-AC05-00OR22725 
This report was prepared as an account of work sponsored by an agency of the United States Government. Neither the United States Government nor any agency thereof, nor any of their employees, makes any warranty, express or implied, or assumes any legal liability or responsibility for the accuracy, completeness, or usefulness of any information, apparatus, product, or process disclosed, or represents that its use would not infringe privately owned rights. Reference herein to any specific commercial product, process, or service by trade name, trademark, manufacturer, or otherwise, does not necessarily constitute or imply its endorsement, recommendation, or favoring by the United States Government or any agency thereof. The views and opinions of authors expressed herein do not necessarily state or reflect those of the United States Government or any agency thereof. 


\section{TABLE CONTENTS}

LIST OF FIGURES iv

LIST OF TABLES. iv

ACROYNMS $\mathrm{v}$

EXECUTIVE SUMMARY vi

1. INTRODUCTION

1.1 CURRENT AND VOLTAGE OPERATING REGION

1.2 CHARACTERISTIC CURRENT OF A PM MOTOR …........................................ 4

1.3 RESEARCH SUMMARY ………………………........................................ 5

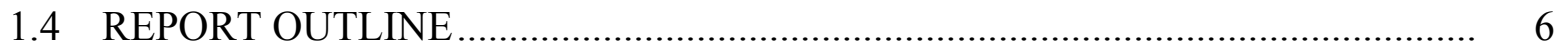

2. FRACTIONAL-SLOT CONCENTRATED WINDINGS

2.1 INTEGER-SLOT WINDING

2.2 EXAMPLE OF A FRACTIONAL-PITCH WINDING ……................................. 8

2.2.1 Fractional-Slot Concentrated Windings................................................. 13

3. EXPERIMENTAL AND ANALYTICAL ANALYSIS OF THE $6 \mathrm{~kW}$

UNIVERSITY OF WISCONSIN/ORNL MOTOR

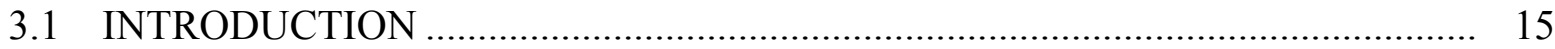

3.2 ORNL 6 kW FRACTIONAL-SLOT MOTOR MODEL WITH

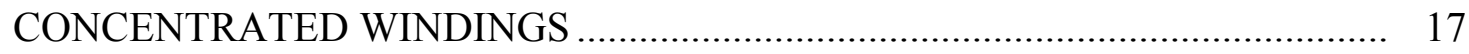

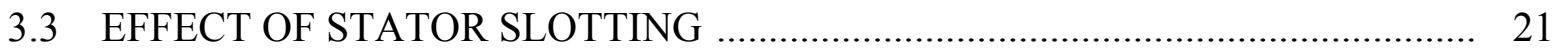

4. MODEL OF AN INTEGER-SLOT PMSM THAT CAN MEET FCVT AND DESIRABLE ADVANCED HEV TRACTION MOTOR SPECIFICATIONS ................ 23

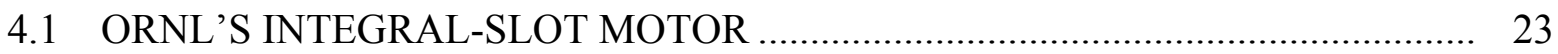

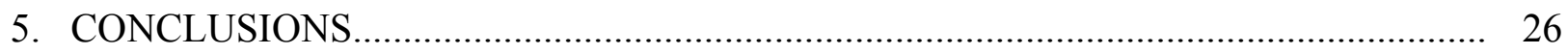

APPENDIX A: USEFUL MATLAB PROGRAMS

A.1 ZHU METHOD FOR CALCULATING BACK-EMF AND

ITS HARMONIC CONTENT …………………………................................... 27

A.2 CALCULATIONS OF THE PERMEANCE FUNCTIONS .................................. 28

APPENDIX B: FCVT SPECIFICATIONS

B.1 FCVT PERFORMANCE GOALS AND TARGETS FOR A 2010 ELECTRIC PROPULSION SYSTEM

B.2 FCVT TECHNICAL TARGETS FOR POWER ELECTRONICS AND ELECTRIC MACHINES.. 
B.3 ADVANCED TRACTION MOTOR SPECIFICATIONS ................................. 31

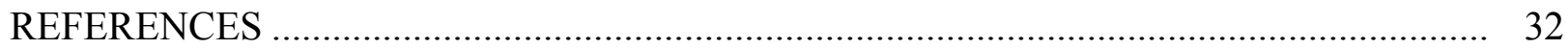

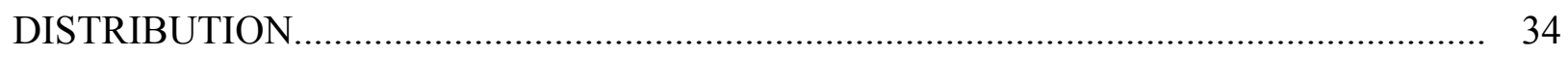




\section{LIST OF FIGURES}

Figure

Page

1 Principal IPM flux paths

2

2

Intersection of voltage ellipse and current circle for an IPM motor ...

5

A three-phase PMSM with surface-mounted magnet .................................................... 7

Winding layout for the PMSM of Table 1 ................................................................ 10

Phasor diagram of non-salient pole (surface-magnet) sinewave motor................... 12

Concentrated windings configurations .......................................................... 13

7 Basic repeating unit of prototype SPM machine consisting of six stator slots and five poles ....................................................................................... 15

8 Configuration of the ORNL model of a $6 \mathrm{~kW}$ fraction-slot PMSM motor

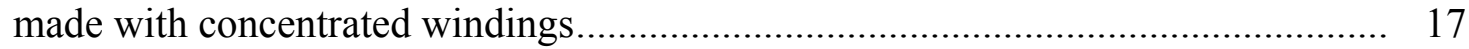

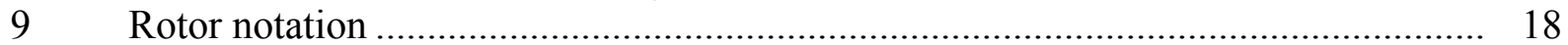

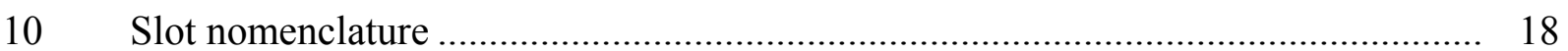

11 One phase of the coil-winding configuration for the ORNL model of a $6 \mathrm{~kW}$ fractional-slot PMSM motor with concentrated windings.................................... 19

12 Peak back-emf per phase of $6 \mathrm{~kW}$ motor at $800 \mathrm{rpm}$........................................ 20

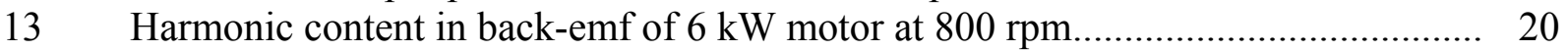

14 Per-phase equivalent circuit of $6 \mathrm{~kW}$ motor ...................................................... 21

15 Relative permeance ................................................................................ 22

16 ORNL's integer-slot PMSM motor model that meets FCVT and desirable advanced HEV traction motor specifications .............................................. 23

\section{LIST OF TABLES}

Table

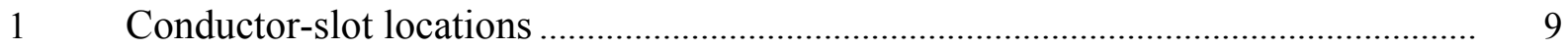

2 Stator dimensions and winding data for the 36-slot/30-pole SPM machine............. 15

3 Rotor dimensions for the 36-slot/30-pole SPM machine.................................... 16

$4 \quad$ Calculated inductances for the 36-slot/30-pole SPM machine ............................. 16

5 Calculated current and magnet parameters for the 36-slot/30-pole SPM machine ... 16

$6 \quad$ Breakdown of material mass for the 36-slot/30-pole SPM machine ...................... 16

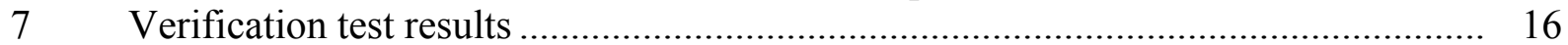

8 Coil locations for ORNL's 6 kW PMSM motor model ......................................... 18

9 Comparison of $6 \mathrm{~kW}$ fractional-slot motor analyses ....................................... 19

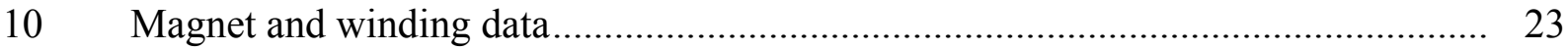

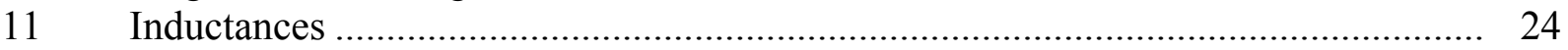

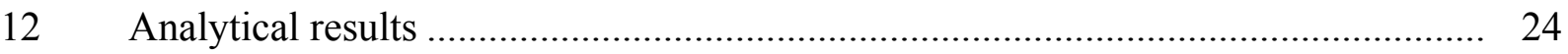

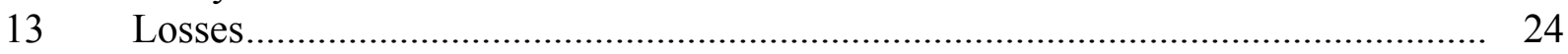




\section{ACRONYMS}

ac

BDCM

CPSR

d-axis

dc

emf

FCVT

FWI

HEV

IM

IPM

$\mathrm{mmf}$

ORNL

PM

PMSM

q-axis

rms

SPM

spp alternating current brushless dc machine constant power speed ratio direct-axis direct current electromotive force FreedomCAR and Vehicle Technologies flux-weakening index hybrid electric vehicle induction motor interior permanent magnet magneto-motive force Oak Ridge National Laboratory permanent magnet permanent magnet surface mounted quadrature-axis root mean square surface permanent magnet slots per pole 


\section{EXECUTIVE SUMMARY}

High-power density and efficiency resulting from elimination of rotor windings and reduced magnetic-flux losses have made the rare earth permanent magnet (PM) motor a leading candidate for the Department of Energy's Office of FreedomCAR and Vehicle Technologies (FCVTs) traction drive motor. These traction drives are generally powered by radial-gap motors, having the magnets on or embedded in a rotating cylinder separated from the inside surface of a slotted cylindrical stator by an annular gap. The two main types of radial-gap PM rotors are those with magnets mounted on the surface of a supporting back iron, called PM surface mounted (PMSM) motors, and those with magnets mounted in slots in the rotor, called interior PM (IPM) motors.

Most early PM motor research was on the PMSM motor, which was thought to have an inherently low stator inductance. A low stator inductance can lead to currents dangerously exceeding rated current as the back-emf across the inductance increases with speed; consequently, part of the attempted solution has been to increase the stator inductance to reduce the rate of current rise. Although analysis suggested that there should be no problem designing sufficiently high stator inductance into PMSMs, attempts to do so were often not successful and a motor design was sought that would have a higher intrinsic inductance.

Commercial research at Toyota has focused on IPM motors because they can achieve a highsaliency ratio, which helps them operate over a high constant power speed ratio (CPSR), but they are more difficult to fabricate. The Oak Ridge National Laboratory's (ORNL) position has been to continue research on brushless direct current (dc) motors (BDCMs) because of ease of fabrication and increased power output.

Recently there has been a revival of interest in a fractional-slot PMSMs [15] made with concentrated windings because they possess three important features. First, they can increase the motor's inductance sufficiently to reduce the characteristic current to value of the rated current, which will enable them to operate at high CPSR. This feature also limits short-circuit fault currents. Second, their segmented structure simplifies assembly problems and is expected to reduce assembly costs. Third, the back-emf waveform is nearly sinusoidal with low cogging.

To examine in depth this design ORNL entered into a collaborative agreement with the University of Wisconsin to build and test a $6 \mathrm{~kW}$ laboratory demonstration unit. Design, fabrication, and testing of the unit to $4000 \mathrm{rpm}$ were completed during FY 2005. The motor will be sent to ORNL to explore ways to control its inverter to achieve higher efficiency during FY 2006.

This paper first reviews the concept of characteristic current and what is meant by optimal flux weakening. It then discusses application of the fractional-slot concentrated winding technique to increase the d-axis inductance of a PMSM showing how this approach differs from an integralslot motor with sinusoidal-distributed windings. This discussion is followed by a presentation of collaborative analyses and comparison with the University of Wisconsin's measured data on a $6 \mathrm{~kW}$, 36-slot, 30-pole motor with concentrated windings. Finally ORNL presents a PMSM design with integral-slot windings that appears to meet the FreedomCAR Specifications, but has some disadvantages. 
Further collaboration with the University of Wisconsin is planned for FY 2006 to design a motor that meets FreedomCAR specifications. 


\section{INTRODUCTION}

High-power density and efficiency resulting from elimination of rotor windings and reduced magnetic-flux losses have made the rare earth permanent magnet (PM) motor a leading candidate for the FreedomCAR and Vehicle Technologies (FCVTs) traction drive motor. These traction drives are generally powered by radial-gap motors, having the magnets on or embedded in a rotating cylinder separated from the inside surface of a slotted cylindrical stator by an annular gap. The two main types of radial-gap PM rotors, those with magnets mounted on the surface of a supporting back iron, called PM surface mounted (PMSM) motors, and those with magnets mounted in slots in the rotor, called interior PM (IPM) motors.

Most early PM motor research was on the PMSM motor, which is thought to have an inherently low stator inductance, $\mathrm{L}_{\text {stator }}$. A low stator inductance can rapidly lead to excessive current, $\mathrm{i}$, above rated current as the voltage across the inductance, $\mathrm{V}$, increases with speed according to the relation $\mathrm{i} \sim \mathrm{Vt} / \mathrm{L}_{\text {stator. The }}$ This relation comes from integration of Lenz's law over short times. Consequently, part of the solution was to increase the stator inductance to reduce the rate of current rise. Although analysis suggested that there should be no problem designing sufficiently high-stator inductance into PMSMs, attempts to do so were often not successful and a motor design was sought that would have a higher intrinsic inductance. Commercial research at Toyota has focused on IPM motors because they can achieve a high-saliency ratio, which helps them achieve high constant power speed ratios (CPSRs), but they are much more difficult to fabricate. Oak Ridge National Laboratory's (ORNLs) position has been to continue research on brushless direct current (dc) motors (BDCMs) because of ease of fabrication and increased power output. Recently there has been a revival of interest in a fractional-slot PMSM made with concentrated windings because they exhibit two very pertinent features. First, they can achieve a stator inductance that is large enough to bring the motor's characteristic current down to the value of the rated current, which will enable them to operate at high CPSR. Second, they are much easier to fabricate.

\subsection{CURRENT AND VOLTAGE OPERATING REGION}

To illustrate how current and voltage regions are determined, we consider the IPM motor of Fig. 1 [1]. Using the Blondel transformation, under which power and peak current are invariant under transformation, we make an axis transformation from the sinusoidally varying $\mathrm{a}, \mathrm{b}$, and $\mathrm{c}$ phase current and voltage coordinates in a stationary reference frame to a synchronously rotating frame in which the currents and voltages are constants during steady state operation. The rotating frame is synchronous because its rotational speed is the same as that of the sinusoidally varying voltage source. The axes in the rotating frame are labeled $\mathrm{d}$, which is chosen to be aligned with a magnet, and q, which is 90 electrical degrees away from the direct-axis (d-axis) along the iron axis as shown in Fig. $1[2,3]$. The equations of motion become

$$
\mathrm{di}_{\mathrm{q}} / \mathrm{dt}=1 / \mathrm{L}_{\mathrm{q}}\left(\mathrm{v}_{\mathrm{q}}-\mathrm{R}_{\mathrm{s}} \mathrm{i}_{\mathrm{q}}-\omega_{\mathrm{e}} \mathrm{L}_{\mathrm{d}} \mathrm{i}_{\mathrm{d}}-\mathrm{E}_{\mathrm{f}}\right)
$$

and

$$
\mathrm{di}_{\mathrm{d}} / \mathrm{dt}=1 / \mathrm{L}_{\mathrm{d}}\left(\mathrm{v}_{\mathrm{d}}-\mathrm{R}_{\mathrm{s}} \mathrm{i}_{\mathrm{d}}+\omega_{\mathrm{e}} \mathrm{L}_{\mathrm{q}} \mathrm{i}_{\mathrm{q}}\right) .
$$


Since $i_{q}$ and $i_{d}$ are constant during steady state operation, which means that $d i_{q} / d t=d i_{d} / d t=0$, the quantities in brackets are zero. Multiplying the bracketed terms in Eqs. (1) and (2) by $i_{q}$ and $i_{d}$ respectively and rearranging to obtain the developed power, $\mathrm{P}-\mathrm{i}^{2} \mathrm{R}_{\mathrm{s}}$, one finds that, neglecting core losses, the available torque for three phases and $\mathrm{m} / 2$ pole pairs is

$$
\mathrm{T}_{\mathrm{e}}=\left\{\mathrm{P}-\left(\mathrm{i}_{\mathrm{d}}{ }^{2}+\mathrm{i}_{\mathrm{q}}{ }^{2}\right) \mathrm{R}_{\mathrm{s}}\right\} / \omega_{\mathrm{m}}=3 / 2\{\mathrm{~m} / 2\}\left\{\left(\mathrm{L}_{\mathrm{d}}-\mathrm{L}_{\mathrm{q}}\right) \mathrm{i}_{\mathrm{d}} \mathrm{i}_{\mathrm{q}}+\mathrm{E}_{\mathrm{f}} \mathrm{i}_{\mathrm{q}} / \omega_{\mathrm{e}}\right\},
$$

where

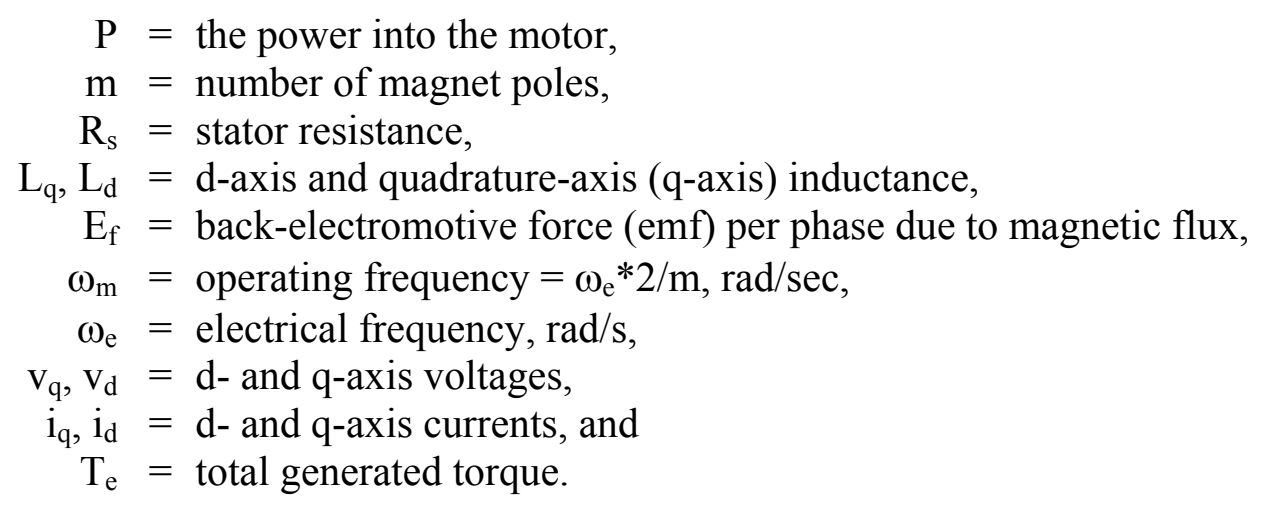

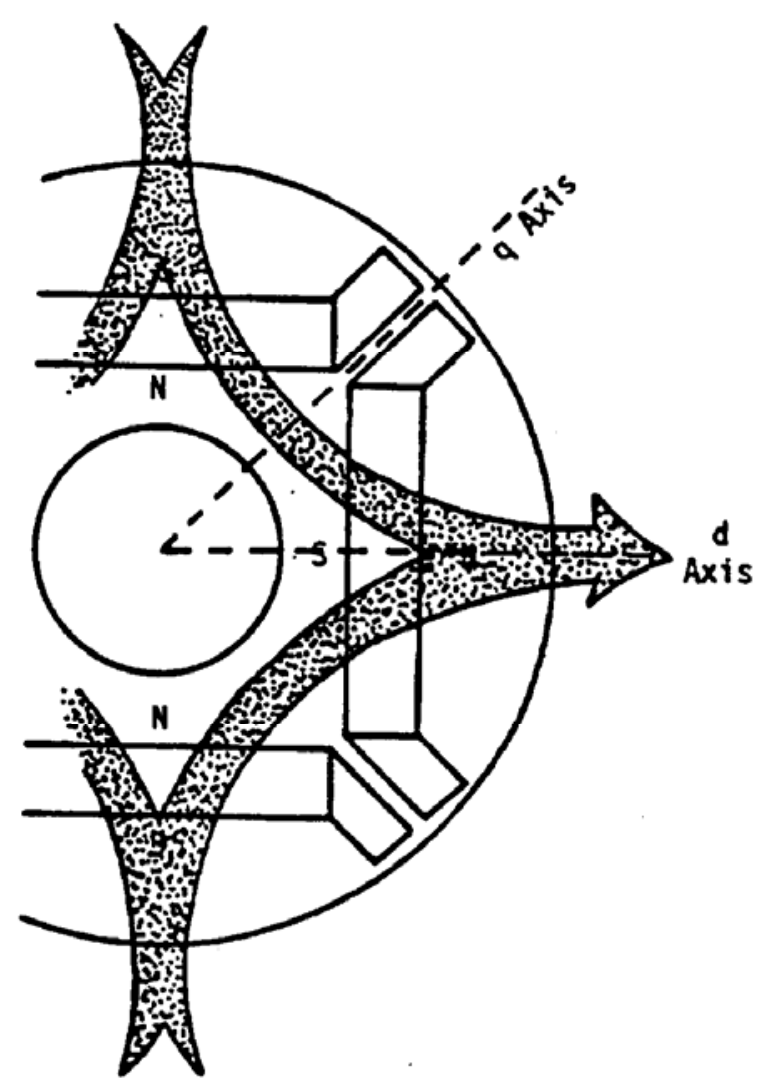

(a) d-axis

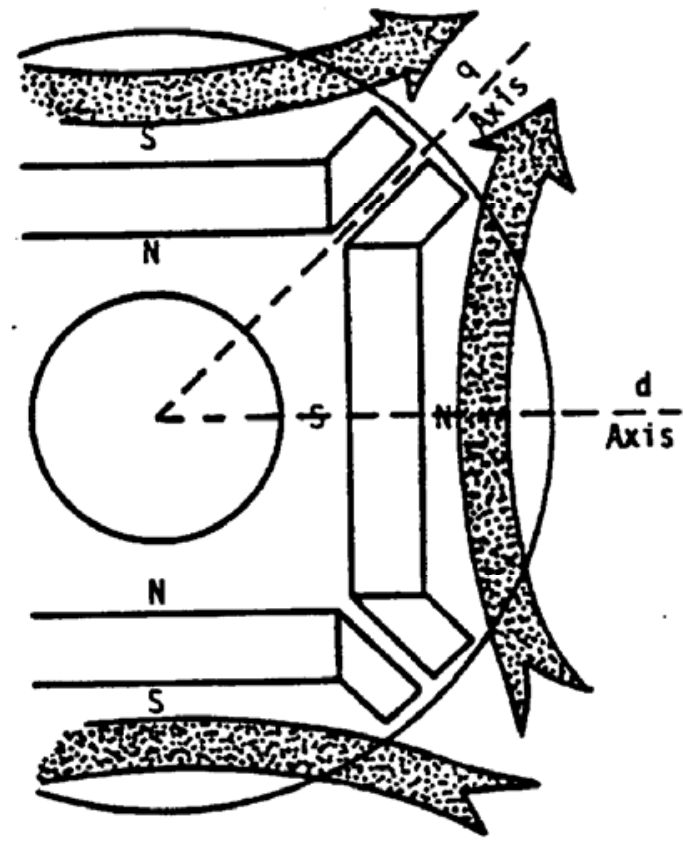

(b) q-axis

Fig. 1. Principal IPM flux paths [1]. 
The rightmost bracketed term is the torque developed per pole, which is multiplied by the number of pole pairs, $\mathrm{m} / 2$, and a factor, 3/2, which makes the power invariant under transformation. In the stationary system when the peak supply currents, $\mathrm{I}_{\mathrm{A}}, \mathrm{I}_{\mathrm{B}}$, and $\mathrm{I}_{\mathrm{C}}$, and voltages, $V_{A}, V_{B}$, and $V_{C}$ are balanced so that $I_{A}=I_{B}=I_{C}$ and $V_{A}=V_{B}=V_{C}$, the transformed power in terms of the current and voltage in the rotating system and in terms of the stationary system is

$$
P=\frac{3}{2}\left[i_{d} v_{d}+i_{q} v_{q}\right]=3 \frac{I_{A}}{\sqrt{2}} \frac{V_{A}}{\sqrt{2}} \cos (\beta)=3 I_{r m s} V_{r m s} \cos (\beta),
$$

where

$$
\begin{aligned}
\beta & =\text { the angle between the supply voltage and current in the stationary system, } \\
I_{r m s} & =\text { the root-mean-square (rms) current in the balanced stationary system, and } \\
V_{r m s} & =\text { the rms voltage in the balanced stationary system. }
\end{aligned}
$$

Likewise, the square of the current and voltage in the rotating system are related to the square of the peak voltage in the stationary system,

$$
i_{d}^{2}+i_{q}^{2}=I_{A}^{2}=2 I_{r m s}^{2} \text { and } v_{d}^{2}+v_{q}^{2}=V_{A}^{2}=2 V_{r m s}^{2} .
$$

For $\mathrm{di}_{\mathrm{q}} / \mathrm{dt}$ and $\mathrm{di}_{\mathrm{d}} / \mathrm{dt}$ not equal to zero, Lopez et al. [4] developed a control scheme where they consider non-zero resistances; however, we shall assume that the resistances are negligible and look at the steady state response where all time derivatives are zero. As mentioned, Eqs. (1) and (2) become

$$
\mathrm{v}_{\mathrm{q}}=\omega_{\mathrm{e}} \mathrm{L}_{\mathrm{d}} \mathrm{i}_{\mathrm{d}}+\mathrm{E}_{\mathrm{f}}
$$

and

$$
\mathrm{v}_{\mathrm{d}}=-\omega_{\mathrm{e}} \mathrm{L}_{\mathrm{q}} \mathrm{i}_{\mathrm{q}}
$$

The locus of constant rated voltage, $\mathrm{V}_{\mathrm{r}}$, and constant rated current, $\mathrm{I}_{\mathrm{r}}$, can be expressed as

$$
\mathrm{V}_{\mathrm{r}}^{2}=\mathrm{v}_{\mathrm{d}}^{2}+\mathrm{v}_{\mathrm{q}}^{2}
$$

and

$$
\mathrm{I}_{\mathrm{r}}^{2}=\mathrm{i}_{\mathrm{d}}^{2}+\mathrm{i}_{\mathrm{q}}^{2}
$$

We now substitute Eqs. (6) and (7) into Eq. (8) to obtain

$$
\mathrm{V}_{\mathrm{r}}^{2}=\left(\omega_{\mathrm{e}} \mathrm{L}_{\mathrm{d}} \mathrm{i}_{\mathrm{d}}+\mathrm{E}_{\mathrm{f}}\right)^{2}+\left(\omega_{\mathrm{e}} \mathrm{L}_{\mathrm{q}} \mathrm{i}_{\mathrm{q}}\right)^{2}
$$


Rewriting Eq. (10) we obtain

$$
\left(\mathrm{V}_{\mathrm{r}} / \omega_{\mathrm{e}} \mathrm{L}_{\mathrm{d}}\right)^{2}=\left(\mathrm{i}_{\mathrm{d}}+\mathrm{E}_{\mathrm{f}} / \omega_{\mathrm{e}} \mathrm{L}_{\mathrm{d}}\right)^{2}+\left(\left(\mathrm{L}_{\mathrm{q}} / \mathrm{L}_{\mathrm{d}}\right) \mathrm{i}_{\mathrm{q}}\right)^{2} .
$$

The voltage frequency ratio, which has the units volt-sec, plays the critical role here and is given the symbol, $\psi_{\mathrm{m}}$, where

$$
\psi_{\mathrm{m}}=\mathrm{E}_{\mathrm{f}} / \omega_{\mathrm{e}}
$$

and is the flux linkages due to the magnet. From Faraday's law, we know that volt-sec equals $\mathrm{N} \phi$ or Weber-Turns. Since the reluctance of the quadrature path is smaller than the reluctance through the direct path because of the magnet thickness, $L_{q}$ is larger than $L_{d}$, we now have the three equations

$$
\begin{aligned}
& \mathrm{I}_{\mathrm{r}}^{2}=\mathrm{i}_{\mathrm{d}}^{2}+\mathrm{i}_{\mathrm{q}}^{2}, \\
& \left(\mathrm{~V}_{\mathrm{r}} / \omega_{\mathrm{e}} \mathrm{L}_{\mathrm{d}}\right)^{2}=\left(\mathrm{i}_{\mathrm{d}}+\psi_{\mathrm{m}} / \mathrm{L}_{\mathrm{d}}\right)^{2}+\left(\left(\mathrm{L}_{\mathrm{q}} / \mathrm{L}_{\mathrm{d}}\right) \mathrm{i}_{\mathrm{q}}\right)^{2},
\end{aligned}
$$

and

$$
\mathrm{T}_{\mathrm{e}}=3 \mathrm{~m} / 4\left\{-\left(\mathrm{L}_{\mathrm{q}}-\mathrm{L}_{\mathrm{d}}\right) \mathrm{i}_{\mathrm{d}} \mathrm{i}_{\mathrm{q}}+\psi_{\mathrm{m}} \mathrm{i}_{\mathrm{q}}\right\}
$$

which means that for an IPM motor, the value of $i_{d}$ must be negative or torque is lost. For a PMSM motor whose $\mathrm{L}_{\mathrm{q}}=\mathrm{L}_{\mathrm{d}}$, negative $\mathrm{i}_{\mathrm{d}}$ is used to oppose the magnet flux with no torque penalty; however, the additional current needed for field weakening produces resistance losses and leads to lower efficiency.

\subsection{CHARACTERISTIC CURRENT OF A PM MOTOR}

We note that $i_{d}$ is the flux-producing component of stator current and $i_{q}$ is the torque-producing component of stator current. From Eqs. (9) and (12), it is seen that the locus of constant rated current $I_{r}$ in the $(d, q)$ plane is a circle centered at the origin and the locus of constant rated voltage is an ellipse centered at $\left(-\psi_{\mathrm{m}} / \mathrm{L}_{\mathrm{d}}, 0\right)$. If the motor has surface PMs (SPMs), the ellipse becomes a circle; however, the ellipse shrinks as the motor speed, $\omega_{\mathrm{e}}$, increases. The two loci are shown in Fig. 2. The motor/inverter must operate within the crosshatched intersection, but as the speed increases and the ellipse shrinks this intersection can disappear depending on the value of $\psi_{\mathrm{m}} / \mathrm{L}_{\mathrm{d}}$. This parameter is so important we give it the name "Characteristic Current" and the symbol $\mathrm{I}_{\mathrm{x}}$,

$$
\mathrm{I}_{\mathrm{x}}=\psi_{\mathrm{m}} / \mathrm{L}_{\mathrm{d}}
$$




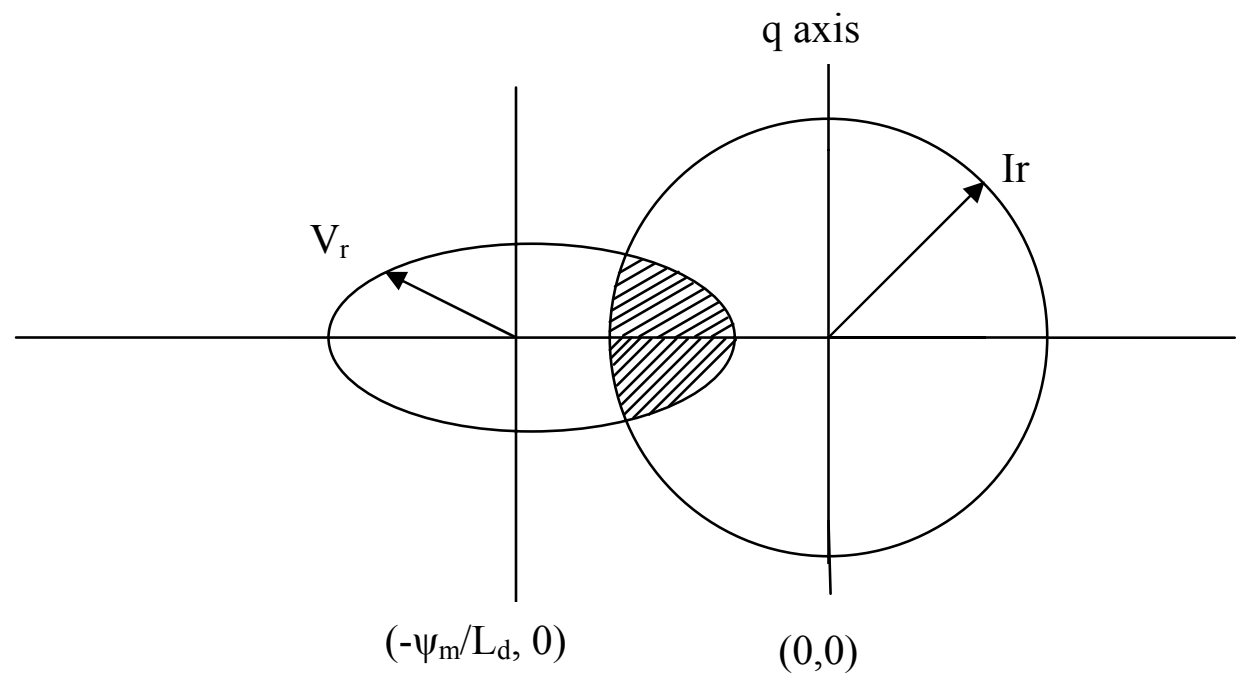

Fig. 2. Intersection of voltage ellipse and current circle for an IPM motor.

We can now see the importance of $I_{x}$ by noting that if the locus of constant rated current intersects the center of the voltage ellipse, then even though the ellipse shrinks there will be an intersection. We summarize with the statement, "If a lossless motor is designed such that its rated current is equal to the characteristic current, it will have an infinite CPSR."

\subsection{RESEARCH SUMMARY}

In the 1980's Sneyers, Novotny, and Lipo [5] first investigated the viability of IPM motors as traction devices and were followed in 1987 by Jahns [1]. Then Schiferl and Lipo [6] in 1990 developed the criteria for optimum field-weakening design criteria expressed by Eq. (16).

However, the seminal paper was that of Soong and Miller [7]. In this paper they normalized the parameters of the motor and introduced the concept of the IPM parameter plane. For the SPM motor, they chose as a design parameter the normalized flux linkage, $\psi_{\mathrm{mn}}$, of Eq. (12). For optimal performance defined to allow infinite CPSR, this value must be

$$
\psi_{\mathrm{mn}}=\frac{1}{\sqrt{2}} .
$$

Furthermore, they state that present day (1980's) SPM motors have values of $\psi_{\mathrm{m}}$ between 0.83 and 0.96 .

Adnanes and Undeland [8] perform a similar normalization but choose $\mathrm{X}_{\mathrm{s}}$, the normalized d-axis reactance, as their parameter. For the SPM motor, the optimal value is again 


$$
\mathrm{X}_{\mathrm{s}}=\frac{1}{\sqrt{2}} \text {. }
$$

They further state that $\mathrm{X}_{\mathrm{s}}$ is typically in the range of $0.3-0.35$.

Both papers concentrate on IPM motors and present day research efforts have followed this trend. While neither paper states that optimum SPM value cannot be obtained, the general thinking has been that

1. Since the magnet is the only source of air-gap flux density, $\psi_{\mathrm{m}}$ must be large, and

2. Since the magnet acts like an additional air gap, the d-axis inductance must be low.

However, the SPM motor is much easier to manufacture than the IPM motor and research efforts have continued with the emphasis on techniques for increasing $L_{d}$ of Eq. (14). In this report, we summarize these research efforts and how they apply to the FCVT program.

\subsection{REPORT OUTLINE}

In Chapter 2 we present our solution to increasing the d-axis inductance of an SPM, namely the use of fractional-slot concentrated windings and how it differs from an integral-slot motor with sinusoidal-distributed windings.

Chapter 3 presents analytical and experimental results for a $6 \mathrm{~kW} \mathrm{36-slot,} \mathrm{30-pole} \mathrm{motor} \mathrm{with}$ concentrated windings.

In Chapter 4, we present a PMSM design with integral-slot windings that appears to meet the FCVT and desirable advanced hybrid electric vehicle (HEV) traction motor specifications but has some disadvantages. 


\section{FRACTIONAL-SLOT CONCENTRATED WINDINGS}

\subsection{INTEGER-SLOT WINDINGS}

Before discussing fractional-slot windings, we review coil parameter definitions and discuss integer-slot windings using as an example the three-phase PMSM with surface-mounted magnets as shown in Fig. 3. To review coil parameters, recall that each coil, which has two sides and two ends, is rectangular with opposite sides referred to as side 1 and side 2 lying in two slots whose angular separation is the coil pitch, $\tau_{\mathrm{p}}$. This angular separation may be defined in mechanical radians, $\omega_{\mathrm{m}}$, or more usefully in electrical radians, $\omega_{\mathrm{e}}$, where $\omega_{\mathrm{e}}=\omega_{\mathrm{m}} \mathrm{p}$ and $\mathrm{p}$ is the number of pole pairs. The angular separation of the two sides determines if the winding is integer-slot or fractional-slot. Angular separation of opposite sides of the coil is referenced to the angular width of one magnet pole so that the word fractional in the term fractional-slot means the fraction of a magnet covered by the coil.

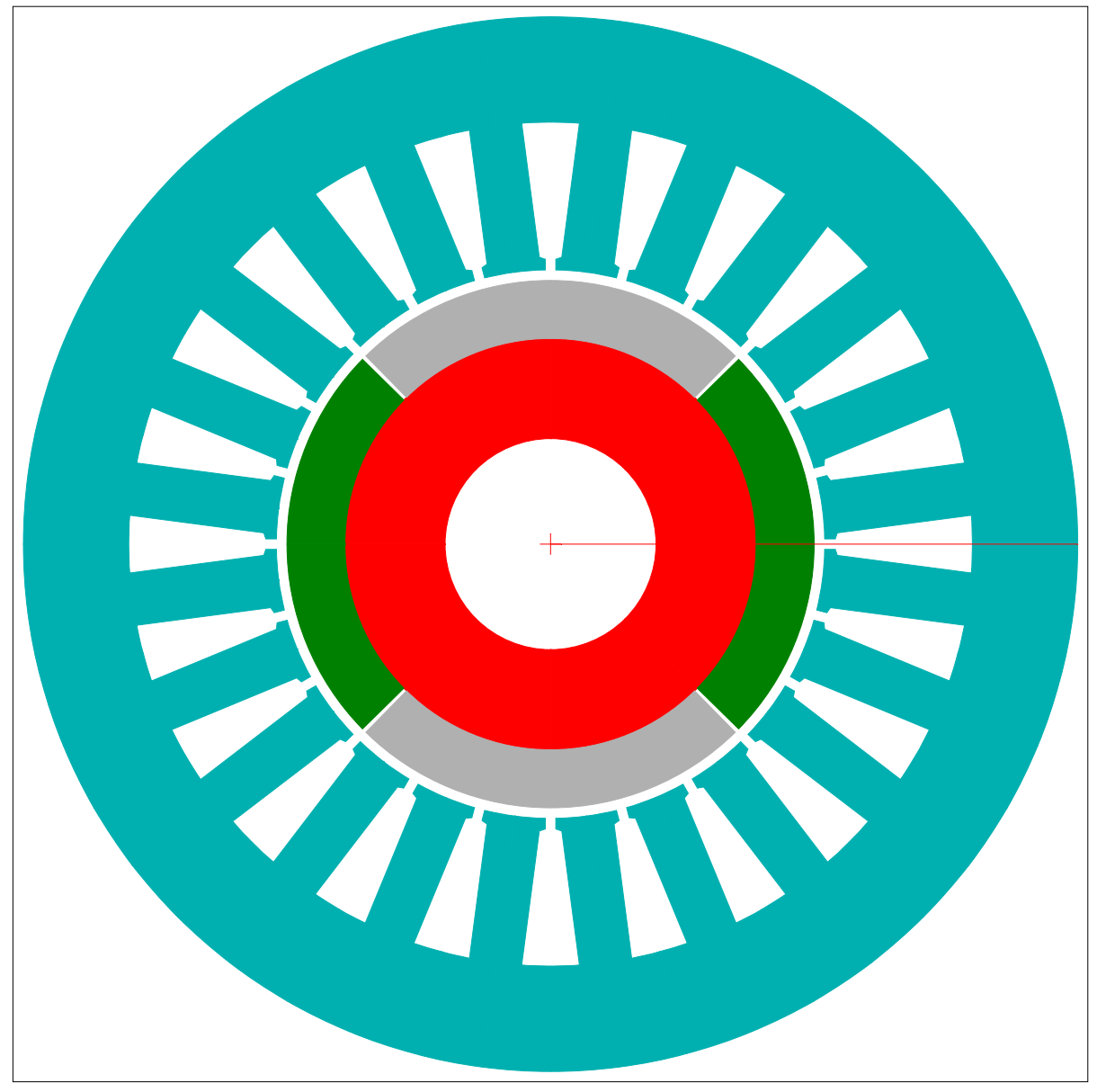

Fig. 3. A three-phase PMSM with surface-mounted magnet.

In Fig. 3 there are 24 slots and 4 poles. An important parameter is the number of slots per pole (spp) per phase, $\mathrm{N}_{\mathrm{spp}}$, given for our example by

$$
\mathrm{N}_{\mathrm{spp}}=24 /(3 * 4)=2
$$


Since this parameter is an integer, we refer to the winding as an integer-slot winding. Typically, these motors have double-layer winding, which means each slot will contain coil sides from two different coils; consequently, there are as many coils as slots. This motor could be wound as a single-layer winding with only 12 coils each wound in slots $180^{\circ}$ apart, but there are advantages to the double layer.

PMSM's have sinusoidal back-emfs and thus must have sinusoidal-distributed windings. The two choices are (1) full pitch or (2) fractional pitch; often termed short chorded because the chord connecting coil side 1 and coil side 2 is shorter than one required to cross a complete magnet pole. A fractional-pitch winding is determined by the ratio of the coil span to the magnet span. If this ratio is unity, the winding is full pitch and if the ratio is less than unity the winding is fractional pitch (short chorded). If this ratio is less than unity, the back-emf will be decreased.

\subsection{EXAMPLE OF A FRACTIONAL-PITCH WINDING}

A sinusoidal-winding configuration of a fractional-pitch winding for the motor of Fig. 3 is summarized in Table 1 and shown in Fig. 4 for a coil with 10 turns. The slot pitch is 15 mechanical degrees, which for two pole pairs (four poles) makes the pitch of one distributed winding 30 electrical degrees. For a full pitch coil, side 1 of coil 1 is in slot 1 and side 2 is in slot 7; however, in Fig. 4 if coil side 1 is in slot 1, side 2 is in slot 6 and we have short chorded by one slot to make the coil span 150 electrical degrees. Since one magnet pole spans 180 electrical degrees, the pitch of this winding is $5 / 6$. The decrease in the back-emf due to the fractional-pitch winding is given by the product of the full pitch back-emf and the pitch factor, $\mathrm{k}_{\mathrm{pn}}$, [3] whose magnitude for any harmonic, $\mathrm{n}$, is

$$
k_{p n}=\left[n \frac{(\text { coil span in electrical degrees })}{2}\right]
$$

Thus by using a fractional-pitch winding and the right-coil span, we can eliminate any harmonic. In our case, the coil span is 150 electrical degrees and the fundamental-voltage component is decreased due to the pitch factor by

$$
\mathrm{k}_{\mathrm{p} 1}=\sin \left(\frac{150}{2}\right)=0.966
$$


Table 1. Conductor-slot locations

$\begin{array}{ccccc}\text { Slot\# } & \text { Phase A } & \text { Phase B } & \text { Phase C } & \text { Total } \\ 1 & 20 & 0 & 0 & 20 \\ 2 & 10 & 0 & -10 & 20 \\ 3 & 0 & 0 & -20 & 20 \\ 4 & 0 & 10 & -10 & 20 \\ 5 & 0 & 20 & 0 & 20 \\ 6 & -10 & 10 & 0 & 20 \\ 7 & -20 & 0 & 0 & 20 \\ 8 & -10 & 0 & 10 & 20 \\ 9 & 0 & 0 & 20 & 20 \\ 10 & 0 & -10 & 10 & 20 \\ 11 & 0 & -20 & 0 & 20 \\ 12 & 10 & -10 & 0 & 20 \\ 13 & 20 & 0 & 0 & 20 \\ 14 & 10 & 0 & -10 & 20 \\ 15 & 0 & 0 & -20 & 20 \\ 16 & 0 & 10 & -10 & 20 \\ 17 & 0 & 20 & 0 & 20 \\ 18 & -10 & 10 & 0 & 20 \\ 19 & -20 & 0 & 0 & 20 \\ 20 & -10 & 0 & 10 & 20 \\ 21 & 0 & 0 & 20 & 20 \\ 22 & 0 & -10 & 10 & 20 \\ 23 & 0 & -20 & 0 & 20 \\ 24 & 10 & -10 & 0 & 20\end{array}$




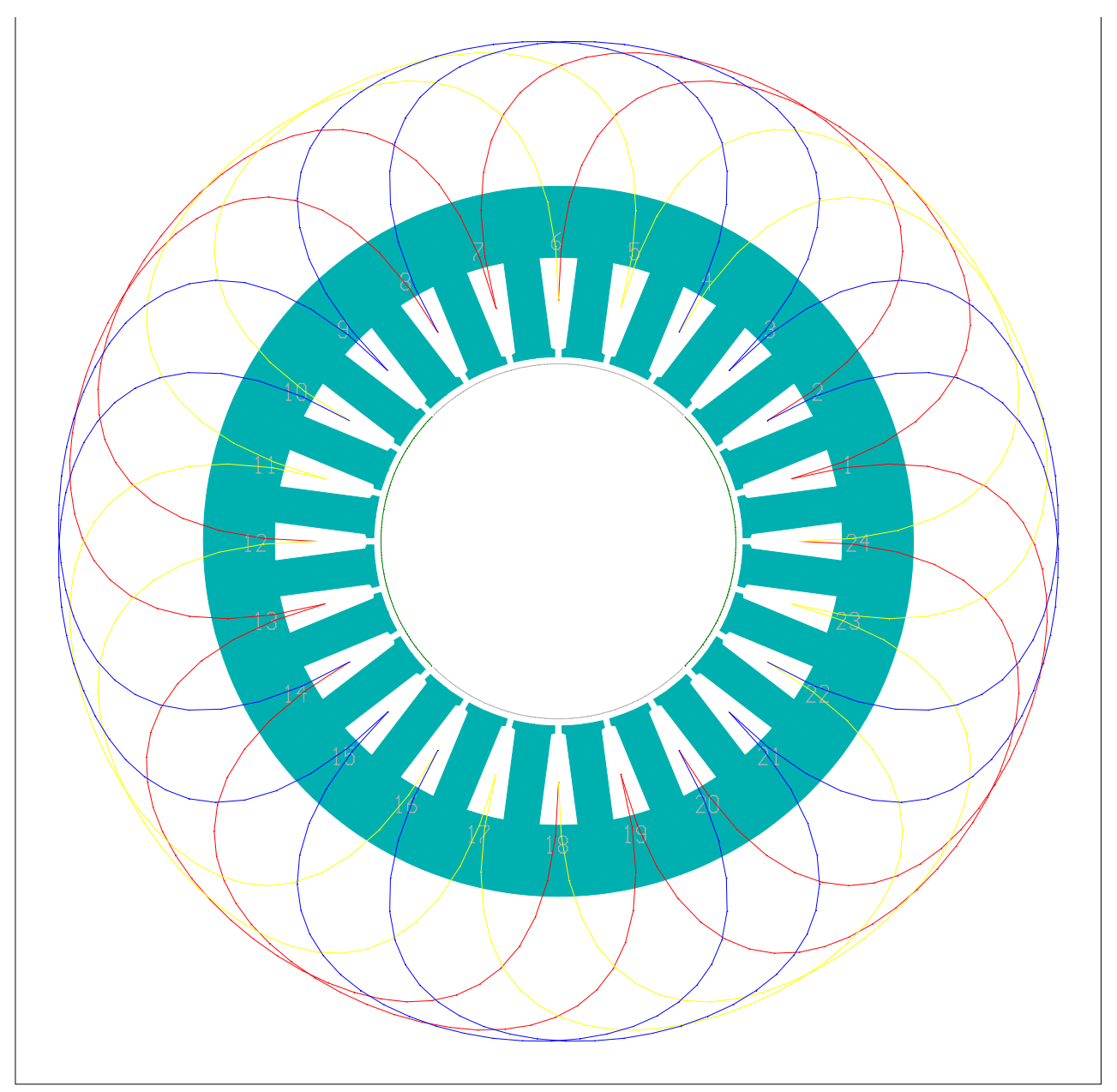

Fig. 4. Winding layout for the PMSM of Table 1.

There is another factor due to the fact that the coils are distributed in space and are displaced from each other by the slot pitch. For an alternating current (ac) winding with $\mathrm{m}$ coils per pole per phase, there is a distribution factor $\mathrm{k}_{\mathrm{d}}[3]$ where

$$
\mathrm{k}_{\mathrm{dn}}=\frac{\sin (n m \alpha / 2)}{m \sin (\alpha / 2)}
$$

and

$$
\alpha=\text { slot angle. }
$$

In our case, $\alpha=30^{\circ}$ and $\mathrm{m}=2$, thus

$$
\mathrm{k}_{\mathrm{d} 1}=\frac{\sin (1 \cdot 2 \cdot 15)}{2 \sin (15)}=0.966 .
$$


We combine these two factors into a winding factor, $\mathrm{k}_{\mathrm{w} 1}$, where

$$
\mathrm{k}_{\mathrm{w} 1}=\mathrm{k}_{\mathrm{d} 1} \mathrm{k}_{\mathrm{p} 1}
$$

Winding factors for the harmonics are developed in [3].

For three-phase PMSM, the open-circuit rms phase back-emf [14] is

$$
\mathrm{E}_{\mathrm{b}}=\frac{2 \pi}{\sqrt{2}}\left(\mathrm{k}_{\mathrm{w} 1} \mathrm{~N}_{\mathrm{ph}}\right) \phi_{\mathrm{ml}} \mathrm{f}
$$

where

$$
\begin{aligned}
\mathrm{k}_{\mathrm{w} 1} & =\text { fundamental winding factor } \\
\mathrm{N}_{\mathrm{ph}} & =\text { series turns per phase } \\
\phi_{\mathrm{m} 1} & =\text { fundamental flux due to the magnet, and } \\
\mathrm{f} & =\text { stator electric supply frequency. }
\end{aligned}
$$

In normal operation, the stator electrical supply frequency (in $\mathrm{rad} / \mathrm{sec}$ ) is made equal to the rotational frequency,

$$
\omega_{\mathrm{e}}=2 \pi \mathrm{f} \mathrm{rad} / \mathrm{sec} \text {. }
$$

The mechanical angular velocity is

$$
\omega_{\mathrm{m}}=\frac{\omega_{\mathrm{e}}}{\mathrm{p}}
$$

where

$$
\mathrm{p}=\text { pole pairs. }
$$

The rms flux linkages of Eq. (10) is

$$
\psi_{\mathrm{m} 1}=\frac{\mathrm{k}_{\mathrm{w} 1} \mathrm{~N}_{\mathrm{ph}} \phi_{\mathrm{m} 1}}{\sqrt{2}},
$$

and Eq. (23) now becomes

$$
\mathrm{E}_{\mathrm{q}}=\omega_{\mathrm{m}} \psi_{\mathrm{m} 1} .
$$

The subscript $\mathrm{q}$ indicates $\mathrm{E}$ is along the q-axis. Using the phase notation of Fig. 5, Eq. (3) can be written as 


$$
\mathrm{Te}=\frac{3}{\omega_{\mathrm{m}}} \mathrm{EI} \sin \beta
$$

During field weakening $I_{d}$ is negative.

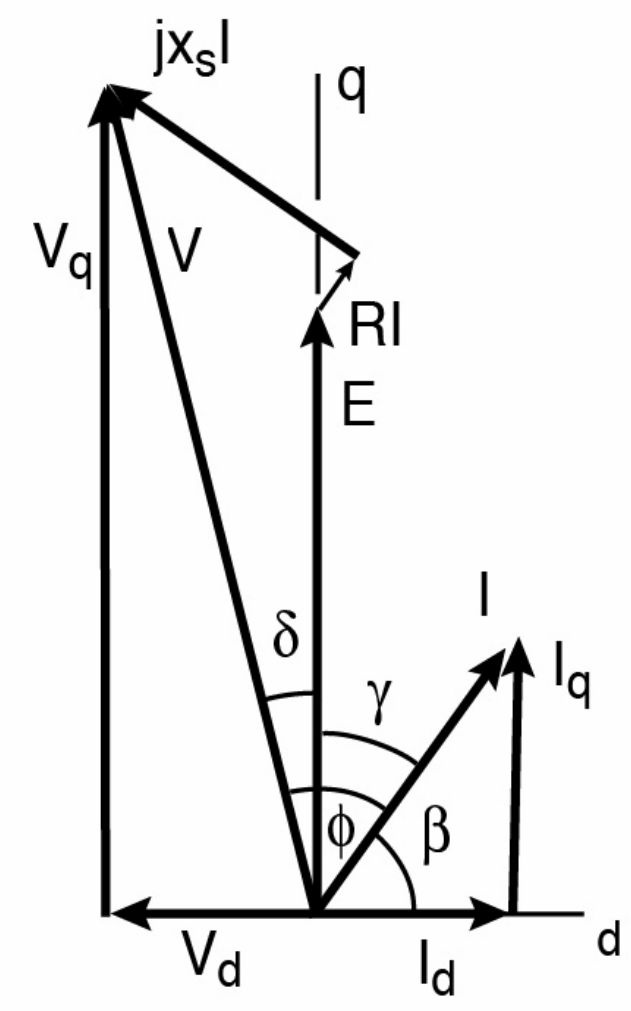

ORNL 2005-02777/jpp

Fig. 5. Phasor diagram of non-salient pole (surface-magnet) sinewave motor.

Adnanes and Undeland [8] normalized and used the d-axis reactance, $\mathrm{x}_{\mathrm{s}}$, to obtain Eq. (16). The $\mathrm{d}$-axis reactance, $\mathrm{x}_{\mathrm{s}}$, consists of two parts, the gap reactance $\mathrm{x}_{\mathrm{g}}$ and leakage reactances

$$
\mathrm{x}_{\mathrm{g}}+\mathrm{x}_{\mathrm{ek}}=\omega_{\mathrm{e}} \mathrm{L}_{\mathrm{d}}
$$

These formulae are not detailed enough to design a real life motor, but they do emphasize the "sine quo non" for a viable PMSM. We now recap these necessities:

(1) The winding configuration must produce a three-phase set of voltages that are balanced; i.e., of equal magnitude and separated by 120 electrical degrees.

(2) The winding factor affects the back-emf and must be high enough to minimize copper loss.

(3) The rms flux density due to the magnet $\phi_{\mathrm{m} 1}$ directly affects the torque and must be relatively large.

(4) The $d$-axis and reactance, $x_{s}$, does not enter into torque production but determines the voltage ellipse of Fig. 2 and hence the CPSR. 
Items (3) and (4) above illustrate the predicament discussed in Chapter 1 and in Eq. (10); i.e., $\psi_{\mathrm{m}}$ is high and $\mathrm{x}_{\mathrm{s}}$ is low.

We now look at concentrated fractional-slot windings and their effects on $\mathrm{kw}$ and $\mathrm{x}_{\mathrm{s}}$.

\subsubsection{Fractional-Slot Concentrated Windings}

It is well known that fractional-slot windings have the advantage of behaving as a winding with many spp [9], thus reducing the distribution factors of the harmonics. Liwschitz [10] has developed the distribution and pitch factors of the harmonics of fractional-slot windings. However, these windings were developed for standard ac machines.

With the emergence of the PMSM with IPMs, the sinusoidal-distributed winding became the winding of choice. However, it was recognized that there were disadvantages [11] which increased the costs in the manufacturing process. The stator became a prime target for cost reduction efforts and concentrated coils [11], where each coil is wound around one tooth became a viable candidate by allowing segmented stator poles and a high slot fill factor ( $70 \%$ compared to $50 \%$ ). Figure 6 shows the different winding configurations.

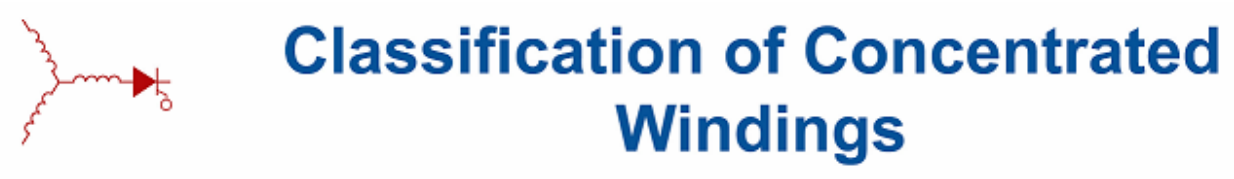

Three Major Categories:
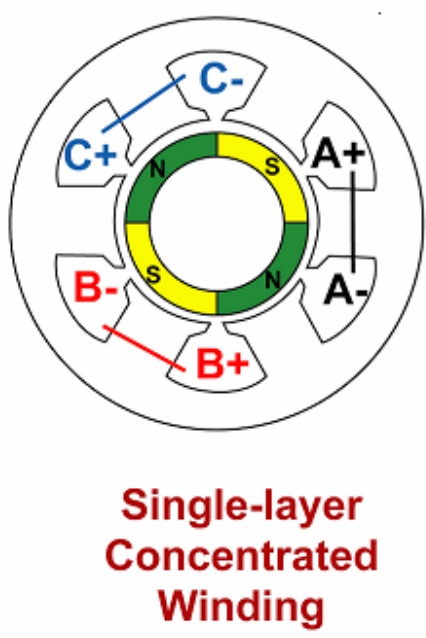
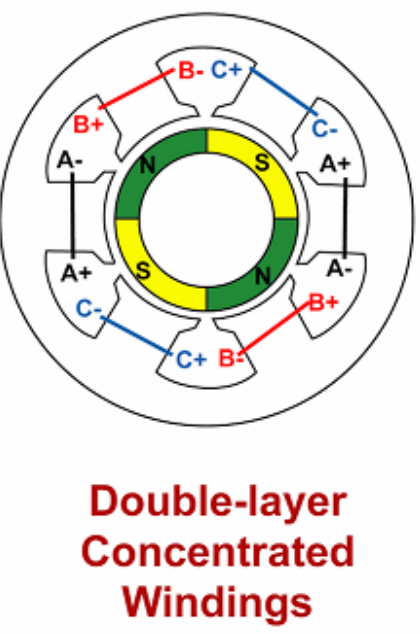
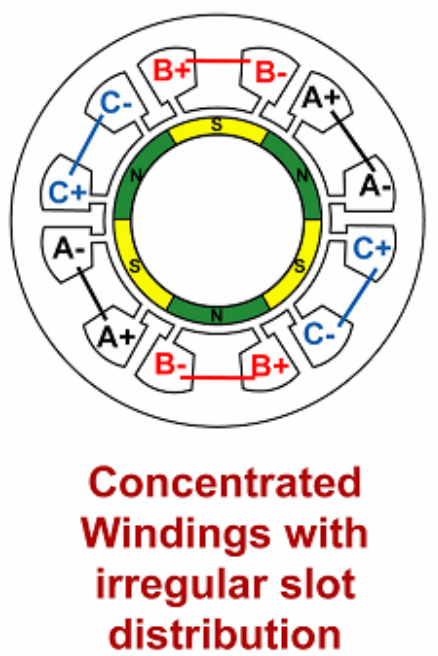

Fig. 6. Concentrated windings configurations.

During this time frame, the electromagnetic design and performance characteristics of PMSMs with surface-mounted magnets and concentrated windings were presented in two papers $[12,13]$. Two important observations are evident: 
(1) There are combinations of slots and poles that allow a fractional-slot concentrated winding to have a high-winding factor and a balanced three-phase output (Table 1 of [12]), and

(2) A characteristic of concentrated windings [13] is that they generate both odd and even magneto-motive force (mmf)-waves which leads to increased leakage inductance. This would also increase the d-axis inductance, $\mathrm{L}_{\mathrm{d}}$, of Eq. (14) and (30) and hence the CPSR of the motor.

The major conclusion of this paper was that SPM machines could be designed to achieve optimal flux-weakening conditions by introducing concentrated fractional-slot stator windings. By optimal conditions, it is meant that the d-axis inductance $L_{d}$ of Eq. (14) can be achieved.

As of this time frame, there were no previous publications that describe specific design techniques for applying such windings to achieve optimal flux-weakening conditions in SPM machines.

This need was then met by El-Refaie and Jahns [15] of the University of Wisconsin when they developed a design technique and applied it to the design of a 36 slot, 42 pole PMSM with fractional-slot concentrated winding and surface-mounted magnets.

The results showed promise as a candidate for the FCVT program and ORNL entered into collaboration with the University of Wisconsin to have them build and test a $6 \mathrm{kw}$, 36-slot/30-pole PMSM with SPMs and concentrated fractional-slot windings. ORNL would use the SPEED program to model the motor and verify its performance with the test data. The experimental results are now available and will be discussed in the next chapter. 


\section{EXPERIMENTAL AND ANALYTICAL ANALYSIS OF THE 6 kW UNIVERSITY OF WISCONSIN/ORNL MOTOR}

\subsection{INTRODUCTION}

The $6 \mathrm{~kW}, 36$-slot/30-pole concentrated winding fraction-slot motor funded by ORNL has now completed its verification testing cycles and both the results and the analytical techniques utilized in the design are published [15]. The basic repeating unit of the SPM machine is shown in Fig. 7.

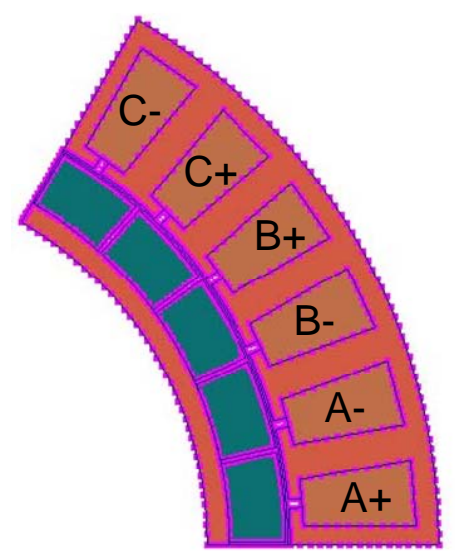

Fig. 7. Basic repeating unit of prototype SPM machine consisting of six stator slots and five poles [15].

The design data and calculated parameters are summarized in Tables $2-6$.

Table 2. Stator dimensions and winding data for the 36-slot/30-pole SPM machine [15]

\begin{tabular}{|c|c|c|c|}
\hline $\begin{array}{c}\text { Number of } \\
\text { slots }\end{array}$ & 36 & Number of poles & 30 \\
\hline $\begin{array}{c}\text { Number of } \\
\text { phases }\end{array}$ & 3 & Slots/pole/phase & $2 / 5$ \\
\hline $\begin{array}{c}\text { Series turns } \\
\text { Number of } \\
\text { coils }\end{array}$ & 108 & $\begin{array}{c}\text { Number of } \\
\text { turns/coil }\end{array}$ & 18 \\
\hline $\begin{array}{c}\text { Outer } \\
\text { diameter }\end{array}$ & $280[\mathrm{~mm}]$ & Active length & $\begin{array}{c}60 \\
\text { paths }\end{array}$ \\
\hline Total length & $72[\mathrm{~mm}]$ & Slot fill factor & $35 \%$ \\
\hline $\begin{array}{c}\text { Slot opening } \\
\text { width }\end{array}$ & $2[\mathrm{~mm}]$ & Slot bottom width & $10[\mathrm{~mm}]$ \\
\hline Slot top width & $14.6[\mathrm{~mm}]$ & Slot opening height & $3[\mathrm{~mm}]$ \\
\hline Slot height & $\begin{array}{c}25.4 \\
{[\mathrm{~mm}]}\end{array}$ & Back iron depth & $9[\mathrm{~mm}]$ \\
\hline Tooth width & $\begin{array}{c}11.4 \\
{[\mathrm{~mm}]}\end{array}$ & Phase resistance & $63[\mathrm{~m} \Omega]$ \\
\hline
\end{tabular}


Table 3. Rotor dimensions for the 36-slot/30-pole SPM machine [15]

\begin{tabular}{|c|c|c|c|}
\hline $\begin{array}{c}\text { Rotor outer } \\
\text { radius }\end{array}$ & $\begin{array}{c}88.6 \\
{[\mathrm{~mm}]}\end{array}$ & $\begin{array}{c}\text { Magnets outer } \\
\text { radius }\end{array}$ & $101.6[\mathrm{~mm}]$ \\
\hline Inner radius & $\begin{array}{c}63.6 \\
{[\mathrm{~mm}]}\end{array}$ & $\begin{array}{c}\text { Air gap } \\
\text { thickness }\end{array}$ & $1[\mathrm{~mm}]$ \\
\hline $\begin{array}{c}\text { Magnet } \\
\text { depth }\end{array}$ & $13[\mathrm{~mm}]$ & Magnet span & $11.4^{\mathrm{o}}[\mathrm{mech}]$ \\
\hline
\end{tabular}

Table 4. Calculated inductances for the 36-slot/30-pole SPM machine [15]

\begin{tabular}{|c|c|l|c|}
\hline $\begin{array}{c}\text { Self inductance } \\
\text { (including harmonic } \\
\text { leakage) }\end{array}$ & $225[\mu \mathrm{H}]$ & $\begin{array}{l}\text { Mutual inductance } \\
\text { (including } \\
\text { harmonic leakage) }\end{array}$ & $\sim 0$ \\
\hline $\begin{array}{c}\text { Self slot leakage } \\
\text { inductance }\end{array}$ & $805[\mu \mathrm{H}]$ & $\begin{array}{l}\text { Mutual slot } \\
\text { leakage inductance }\end{array}$ & $\sim 0$ \\
\hline $\begin{array}{c}\text { Total self } \\
\text { inductance }\end{array}$ & $1.03[\mathrm{mH}]$ & $\begin{array}{l}\text { Net mutual } \\
\text { inductance }\end{array}$ & $\sim 0$ \\
\hline
\end{tabular}

Table 5. Calculated current and magnet parameters for the 36-slot/30-pole SPM machine [15]

\begin{tabular}{|l|c|l|c|}
\hline $\begin{array}{l}\text { Magnet remanent flux } \\
\text { density, Br }\end{array}$ & 0.55 [Tesla] @ $100^{\circ} \mathrm{C}$ & $\begin{array}{l}\text { Magnet relative } \\
\text { permeability, } \mu \mathrm{r}\end{array}$ & 1.22 \\
\hline RMS PM flux linkage $\Psi \mathrm{m}$ & $34.8[\mathrm{mWb}-\mathrm{rms}]$ & $\begin{array}{l}\text { RMS characteristic } \\
\text { current, Ich= }=\text { m/Ld }\end{array}$ & $33.8[$ Arms] \\
\hline RMS rated current, IR & $43[$ Arms] & $\begin{array}{l}\text { Flux=weakening index } \\
\text { FWI =Ich/ IR }\end{array}$ & 0.79 \\
\hline Copper current density & $7[$ Arms $/ \mathrm{mm} 2]$ & Air-gap shear stress & $3.1[\mathrm{psi}]=21[\mathrm{kPa}]$ \\
\hline
\end{tabular}

Table 6. Breakdown of material mass for the 36-slot/30-pole SPM machine [15]

\begin{tabular}{|l|c|l|c|}
\hline Copper mass & $2.8[\mathrm{~kg}]$ & Iron mass & $12.6[\mathrm{~kg}]$ \\
\hline Magnet mass & $3.6[\mathrm{~kg}]$ & Total mass & $19[\mathrm{~kg}]$ \\
\hline
\end{tabular}

The analytical and experiment results of the verification tests are shown in Table 7.

Table 7. Verification test results [15]

\begin{tabular}{|c|c|c|c|c|c|c|c|c|c|c|}
\hline & & \multicolumn{8}{|c|}{$100 \%$ load } & \multirow[t]{2}{*}{$\mathrm{P}_{\text {out }} / \mathrm{P}_{\text {in }}$} \\
\hline $\mathrm{rpm}$ & $\mathrm{mech} \mathrm{rad} / \mathrm{s}$ & $\mathrm{I}_{\mathrm{q}}$ & $\mathrm{I}_{\mathrm{d}}$ & I & $V_{\text {phase }}$ & $P_{\text {in }}=3 \mathrm{IV}_{\text {phase }}$ & $\mathrm{T}_{\text {out }}$ & $\mathrm{P}_{\text {out }}$ & Eff & \\
\hline & & Amps & Amps & Amps & Volts & Volt-amps & $\mathrm{N}-\mathrm{m}$ & Watts & $\%$ & \\
\hline 800 & 83.78 & 43.0 & 0.0 & 43 & 85.0 & 10965 & 60 & 4901 & 86.0 & 44.7 \\
\hline 2000 & 209.44 & 21.6 & -26.7 & 34.3 & 87.7 & 9035.675 & 30.5 & 6392 & 91.0 & 70.74 \\
\hline 3000 & 314.16 & 14.4 & -26.5 & 30.2 & 87.7 & 7935.028 & 20.4 & 6415 & 92.0 & 80.84 \\
\hline 4000 & 418.88 & 10.8 & -26.4 & 28.5 & 87.7 & 7504.579 & 15.3 & 6404 & 91.9 & 85.33 \\
\hline \multicolumn{11}{|c|}{ Experimental } \\
\hline 800 & 83.78 & 43.0 & 0.0 & 43 & 81.0 & 10449 & 64 & 5400 & 84.0 & 51.68 \\
\hline 2000 & 209.44 & 24.8 & -26.9 & 36.6 & 89.0 & 9768.88 & 29 & 6075 & 90.3 & 62.19 \\
\hline 3000 & 314.16 & 18.4 & -14.6 & 23.5 & 91.0 & 6412.421 & 19.4 & 6099 & 90.0 & 95.11 \\
\hline 4000 & 418.88 & 16.6 & -14.9 & 22.3 & 91.0 & 6089.614 & 14.7 & 6146 & 91.7 & 100.9 \\
\hline
\end{tabular}


It is noteworthy that bonded neodymium-iron-boron magnets were utilized to minimize eddycurrent losses in the magnets. Because of its relatively low $\mathrm{Br}(0.55 \mathrm{~T})$ and relative permeability $\mu \mathrm{r}$ (1.22), its length of $13 \mathrm{~mm}$ is large compared to that of an induction motor (IM). Also unlike IMs, the slot-leakage inductance was almost a factor of four higher than the self inductance.

The important result is shown in Table 5 which shows the flux-weakening index (FWI),

$$
\mathrm{FWI}=\frac{\mathrm{I}_{\mathrm{ch}}}{\mathrm{I}_{\mathrm{r}}}=0.79
$$

This means the $d$-axis inductance $L_{d}$ is higher than the optimal value so that the rated current is smaller than the characteristic current; however, as seen in Table 7 and in [15] the motor meets its goal of CPSR $=6$.

We now compare the results with the results of the ORNL calculations, which employ the SPEED software.

\section{$3.2 \quad$ ORNL 6 kW FRACTIONAL-SLOT MOTOR MODEL WITH CONCENTRATED WINDINGS}

Using the data from Table 1, the motor as represented in the SPEED program is shown in Fig. 8. The nomenclature is shown in Figs. 9 and 10. Table 8 shows the coil locations and shows that this is indeed a single-layer winding. Each of the 18 coils is wrapped around a separate tooth and each slot has only one coil side inserted. Figure 11 is the winding diagram for one phase. Comparing Figs. 8 and 11 with Fig. 7 we find that the repeating unit of 6 stator slots and 5 poles is evident.

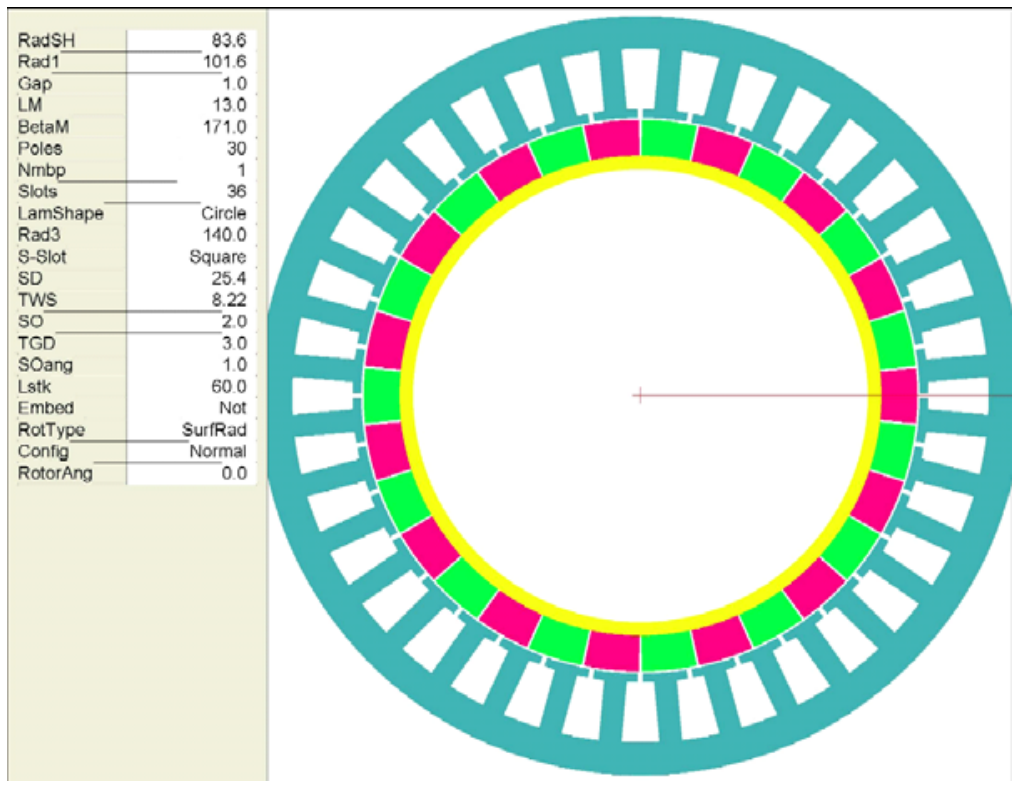

Fig. 8. Configuration of the ORNL model of a $6 \mathrm{~kW}$ fraction-slot PMSM motor made with concentrated windings. 


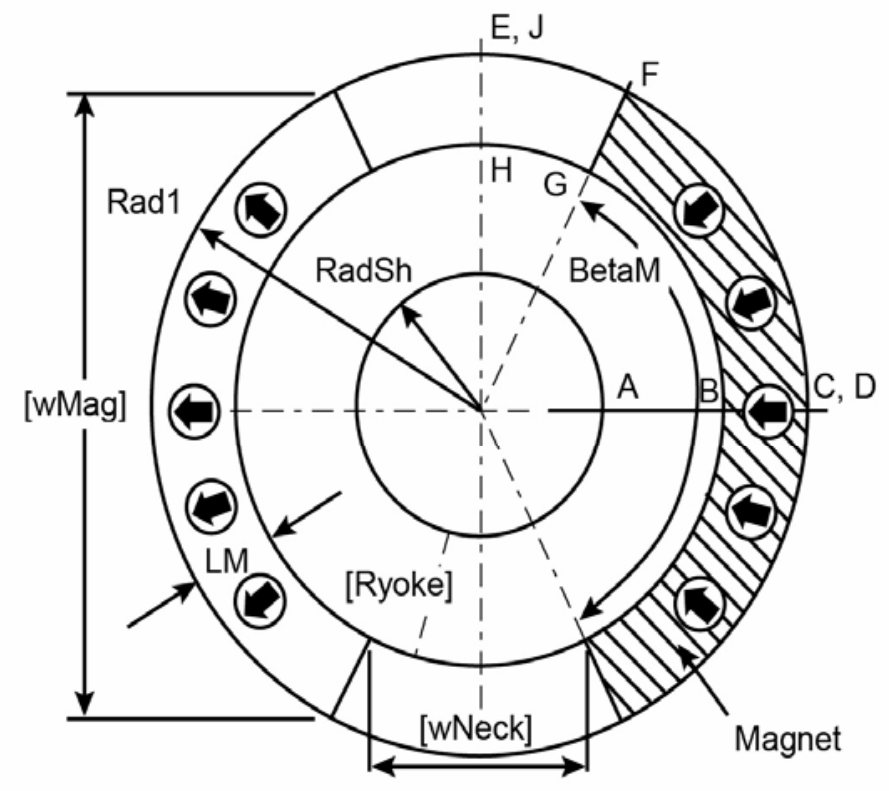

RotType $=$ SurfRad, Embed $=$ Not

ORNL 2005-03061

Fig. 9. Rotor notation.

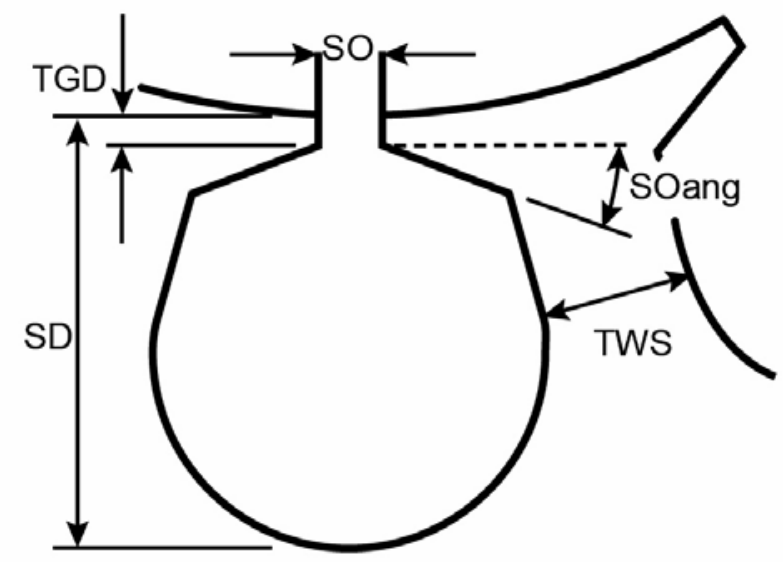

ORNL 2005-03064

Fig. 10. Slot nomenclature

Table 8. Coil locations for ORNL's 6 kW PMSM motor model

\begin{tabular}{|c|c|c|c|c|c|c|c|c|c|c|c|c|c|c|}
\hline \multicolumn{1}{|c|}{ Phase A } & \multicolumn{1}{|c|}{ Phase B } & \multicolumn{5}{c|}{ Phase C } \\
\hline Coil & From & To & Thr & Turns & Coil & From & To & Thr & Turns & Coil & From & To & Thr & Turns \\
\hline 1 & 1 & 2 & 1 & 18 & 1 & 9 & 10 & 1 & 18 & 1 & 17 & 2 & 1 & 18 \\
\hline 2 & 8 & 7 & -1 & 18 & 2 & 16 & 15 & -1 & 18 & 2 & 24 & 7 & -1 & 18 \\
\hline 3 & 13 & 14 & 1 & 18 & 3 & 21 & 22 & 1 & 18 & 3 & 29 & 14 & 1 & 18 \\
\hline 4 & 20 & 19 & -1 & 18 & 4 & 28 & 27 & -1 & 18 & 4 & 36 & 19 & -1 & 18 \\
\hline 5 & 25 & 26 & 1 & 18 & 5 & 33 & 33 & 1 & 18 & 5 & 5 & 26 & 1 & 18 \\
\hline 6 & 32 & 31 & -1 & 18 & 6 & 4 & 4 & -1 & 18 & 6 & 12 & 31 & -1 & 18 \\
\hline
\end{tabular}




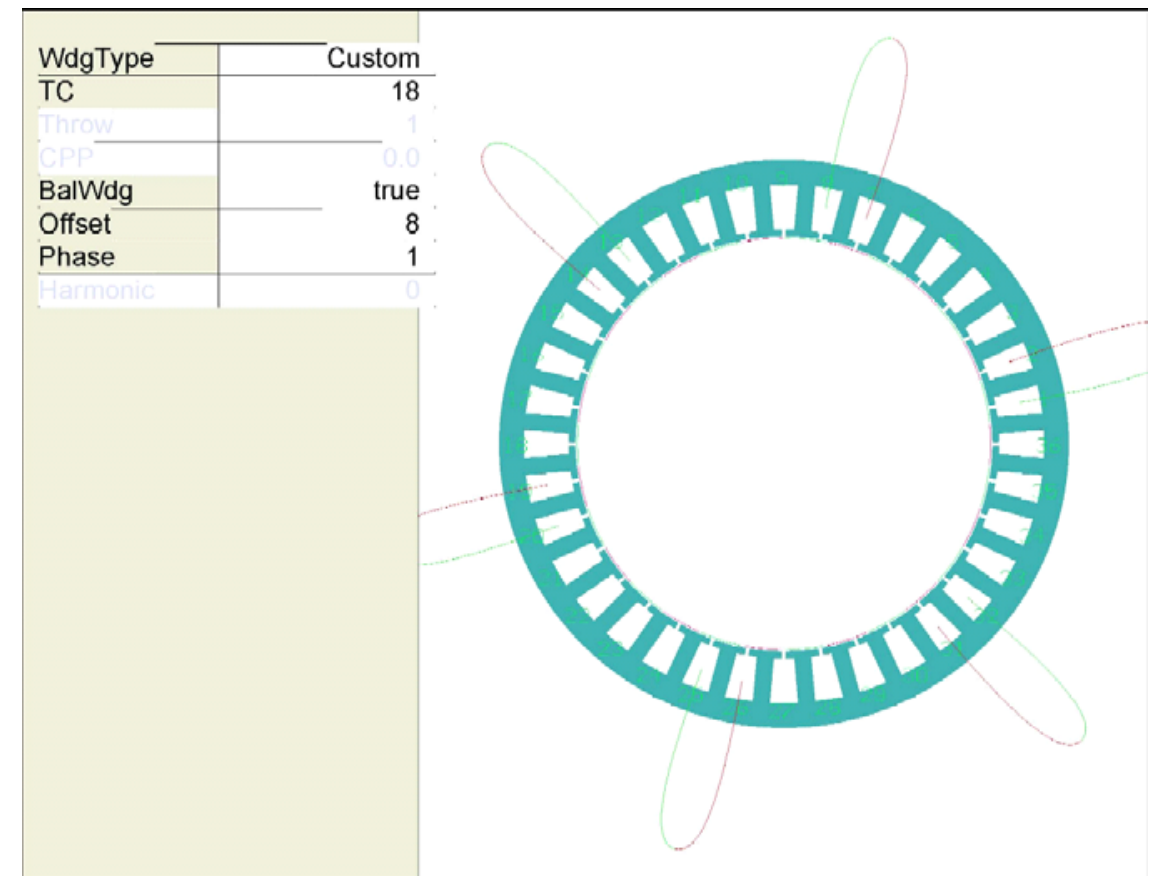

Fig. 11. One phase of the coil-winding configuration for the ORNL model of a $6 \mathrm{~kW}$ fractional-slot PMSM motor with concentrated windings.

Calculations by the University of Wisconsin and ORNL for the $6 \mathrm{~kW}$ fractional-slot motor with concentrated windings are compared in Table 9.

Table 9. Comparison of 6 kW fractional-slot motor analyses

\begin{tabular}{|c|c|c|}
\hline Parameters per phase & Wisconsin & ORNL (SPEED software) \\
\hline Gap inductance & $0.225 \mathrm{mh}$ & $0.293 \mathrm{mh}$ \\
\hline Slot inductance & $0.805 \mathrm{mh}$ & $0.767 \mathrm{mh}$ \\
\hline End-turn inductance & - & $0.04 \mathrm{mh}$ \\
\hline Total stator inductance & $1.03 \mathrm{mh}$ & $1.1 \mathrm{mh}$ \\
\hline Resistance & $0.063 \mathrm{~m} \Omega$ & $0.047 \mathrm{~m} \Omega$ \\
\hline Back-emf & $41.87 \mathrm{rms}$ volts & $55.75 \mathrm{rms}$ volts \\
\hline
\end{tabular}

The most significant deviation is the $33 \%$ difference of the back-emf. In discussions with the University of Wisconsin, it was determined that SPEED uses a one-dimensional analysis to model the air-gap flux density, whereas the University of Wisconsin uses the technique of Zhu [17], which is based on a two-dimensional solution of LaPlace's equation. Using this technique, the back-emf of Fig. 12 was generated. From its harmonic content, as shown in Fig. 13, the fundamental rms back-emf per phase at $800 \mathrm{rpm}$ becomes

$$
E=45 V_{\text {phase }}^{\text {rms }}
$$




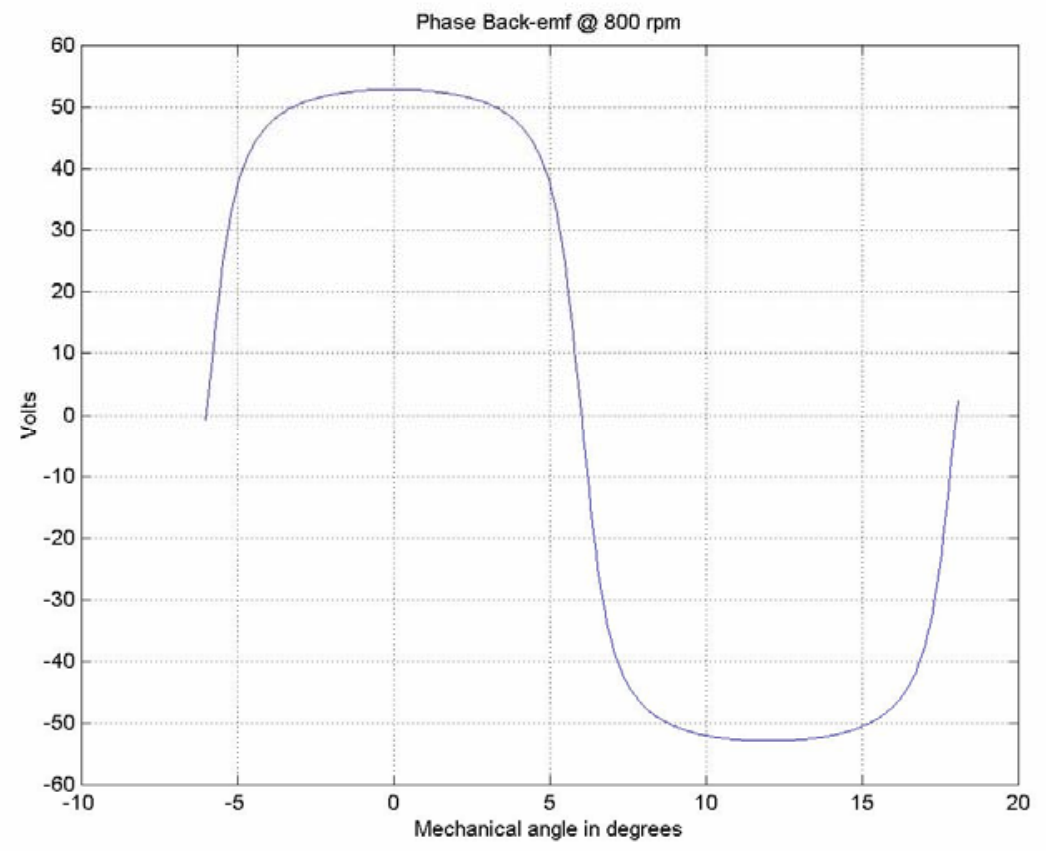

Fig. 12. Peak back-emf per phase of $6 \mathrm{~kW}$ motor at $800 \mathrm{rpm}$.

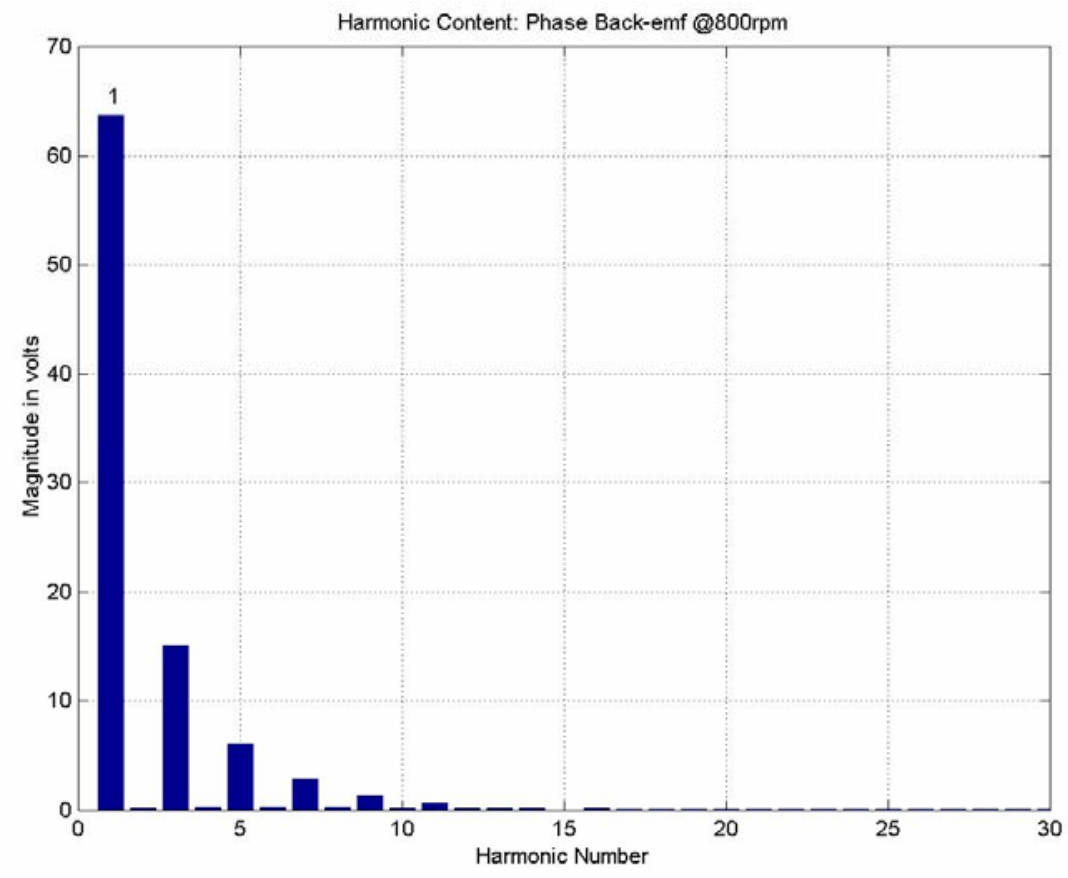

Fig. 13. Harmonic content in back-emf of $6 \mathrm{~kW}$ motor at $800 \mathrm{rpm}$.

The MATLAB program used to calculate the back-emf and harmonic content are listed in Appendix A. 
In general, there is good correlation between ORNL and the University of Wisconsin analyses and the actual motor response. The $6 \mathrm{~kW}$ motor, as analyzed in the SPEED program, can be approximately modeled by the circuit of Fig. 14 . The winding resistances differ, but they do not dramatically affect the results.

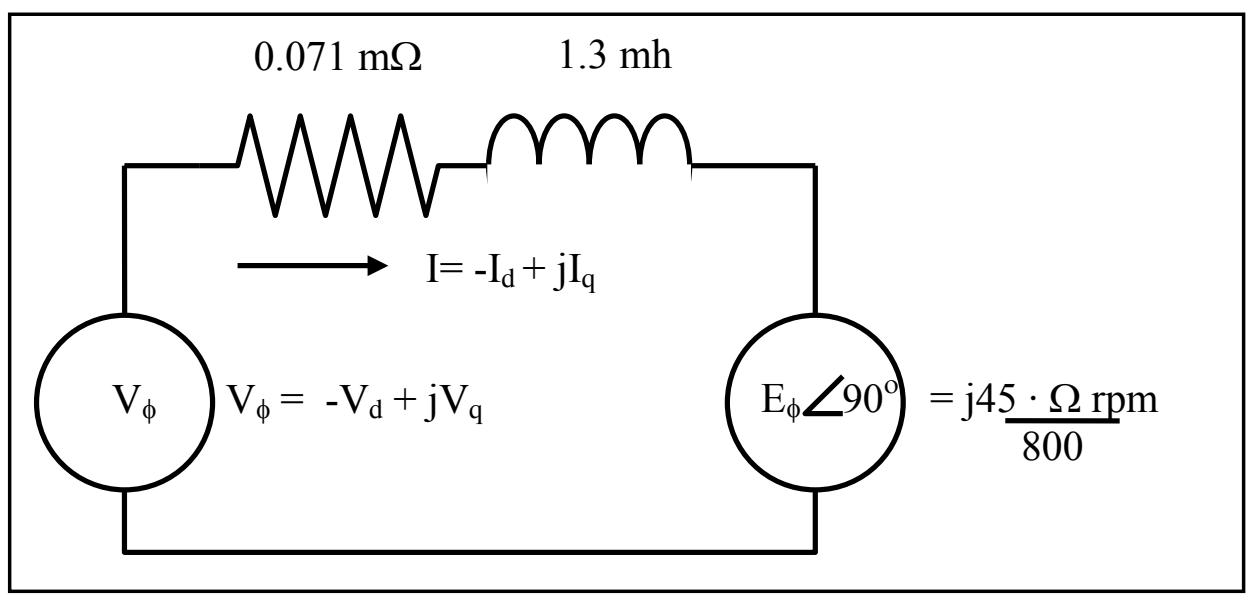

Fig. 14. Per-phase equivalent circuit of $6 \mathrm{~kW}$ motor.

\subsection{EFFECT OF STATOR SLOTTING [16]}

Slotting influences the magnetic field in two ways:

1. It reduces the total flux per pole by increasing the effective air gap.

This effect is accounted for by the Carter Coefficient, $\mathrm{k}_{\mathrm{c}}$; and

2. It affects the distributions of the flux in both the air gap and the magnets.

To account for the second effect, the Fourier permeance function, $\lambda(\theta)$, is introduced in Fig. 15. The back-emf is then multiplied by this function for the corrected back-emf, which is given by

$$
E^{\prime}=E \bullet \lambda(\theta)
$$

The MATLAB program used to calculate this function is in Appendix A. 


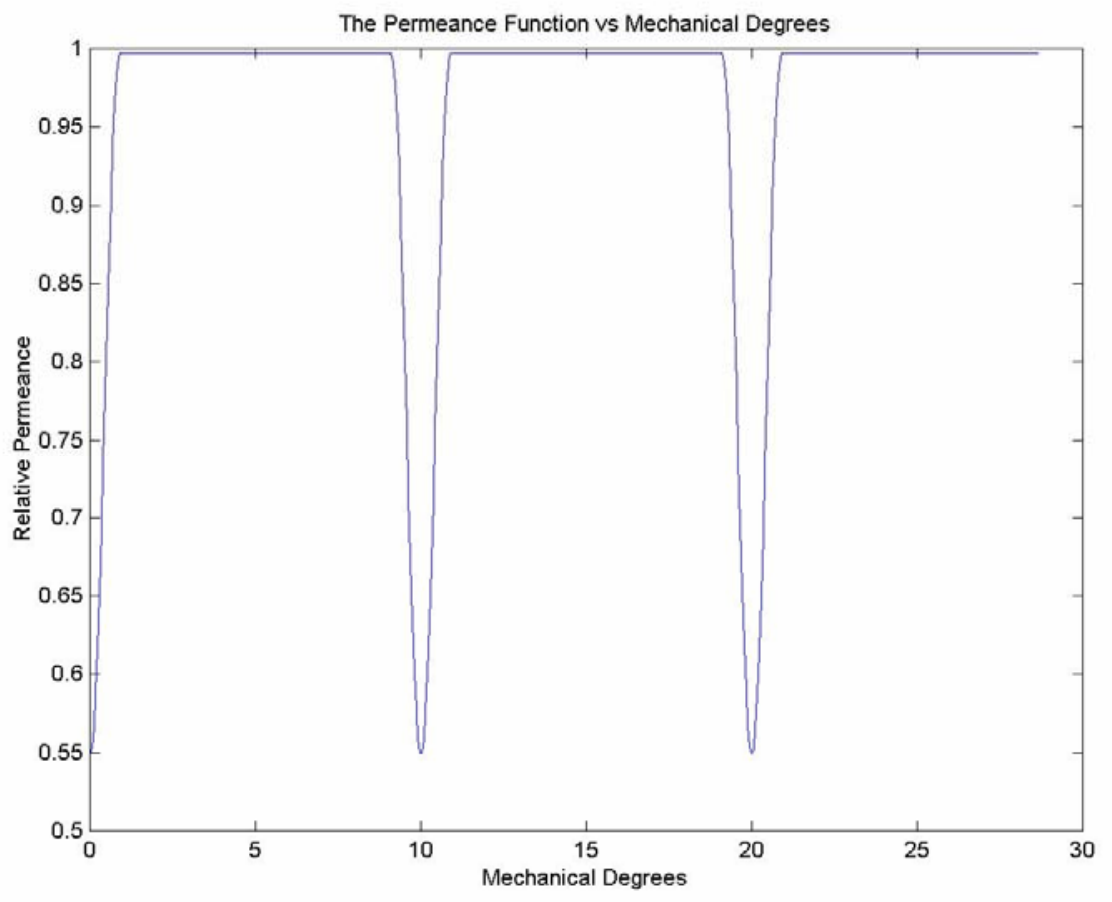

Fig. 15. Relative permeance. 


\section{MODEL OF AN INTEGER-SLOT PMSM THAT CAN MEET FCVT AND DESIRABLE ADVANCED HEV TRACTION MOTOR SPECIFICATIONS}

The next step in ORNLs FCVT program is to collaborate with the University of Wisconsin to design, build, and test a fractional-slot motor with concentrated windings and other PMSMs that meet the FCVT specifications in Appendices B.1 and B.2 along with desirable industrial specifications in Appendix B.3.

At the same time, ORNL is pursuing the design of an integral-slot motor. The intent is to use this design to show why the fractional-slot motor is a viable candidate for the FCVT traction drive. A preliminary design of such an integral-slot motor is discussed in the following sections.

\subsection{ORNL'S INTEGRAL-SLOT MOTOR}

The preliminary design is shown in Fig. 16. Recognizing that the losses will play a large role in this design, the lamination material was chosen as Arnon 7, which is 7 mils thick. The parameters used in the analysis are shown in Tables 10-13.

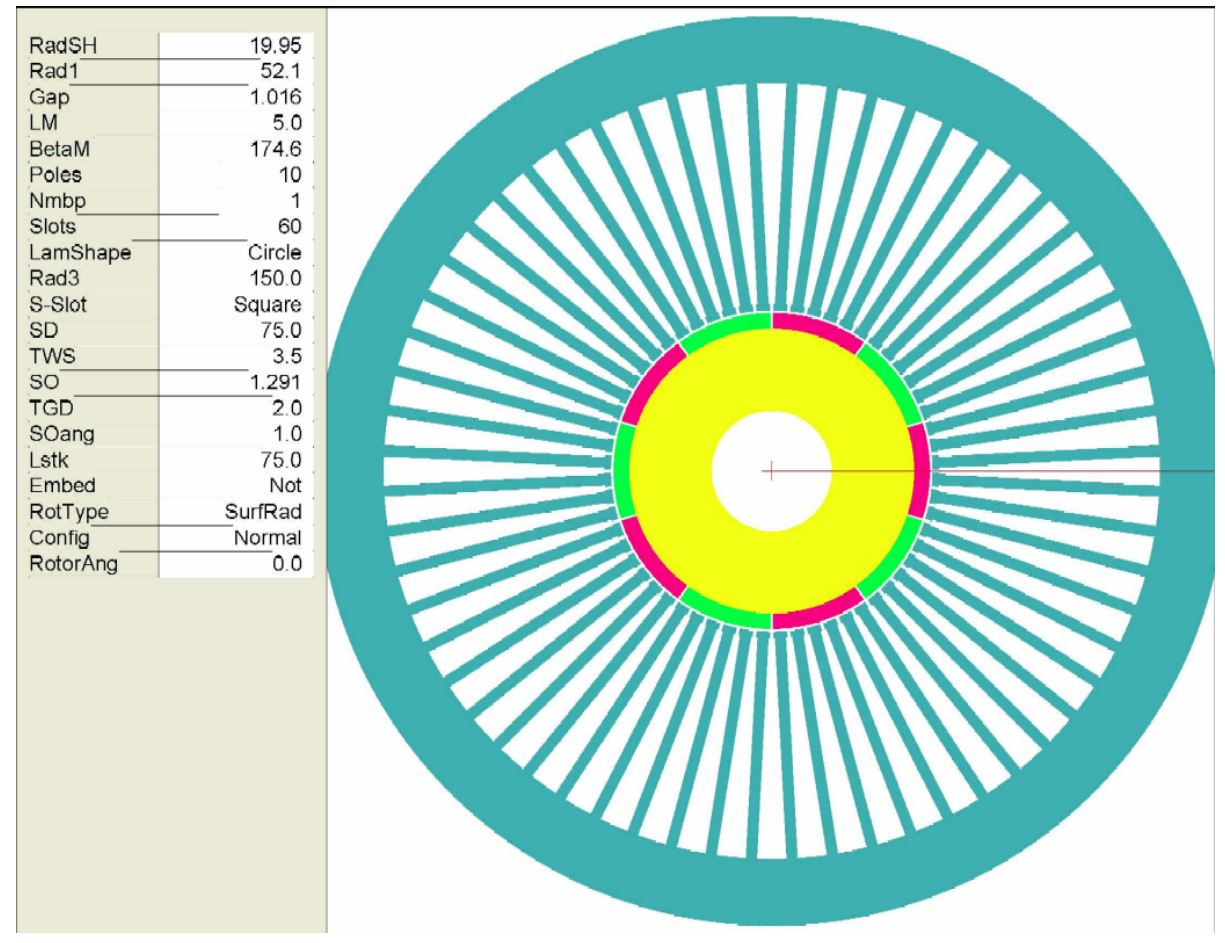

Fig. 16. ORNL's integer-slot PMSM motor model that meets FCVT and desirable advanced HEV traction motor specifications.

Table 10. Magnet and winding data

\begin{tabular}{|c|c|c|c|}
\hline Wire size & $1.291 \mathrm{~mm}$ & Magnet material & Incor \\
\hline Strands in hand NSH & 32 & $\mathrm{~B}_{\mathrm{r}}$ & 0.940 \\
\hline Turns/coil & 2 & $\mathrm{H}_{\mathrm{c}}$ & $660 \mathrm{kA} / \mathrm{m}$ \\
\hline Turns/phase & 40 & $\mu_{\mathrm{r}}$ & 1.05 \\
\hline
\end{tabular}


Table. 11. Inductances

\begin{tabular}{|c|c|c|c|}
\hline $\mathrm{L}_{\mathrm{ph}}$ & $0.299 \mathrm{mh}$ & $\mathrm{M}_{\mathrm{ph}}$ & $-0.054 \mathrm{mh}$ \\
\hline $\mathrm{L}_{\text {slot }}$ & $0.137 \mathrm{mh}$ & $\mathrm{M}_{\text {slot }}$ & $-0.023 \mathrm{mh}$ \\
\hline $\mathrm{L}_{\mathrm{g}}$ & $0.070 \mathrm{mh}$ & $\mathrm{M}_{\mathrm{g}}$ & $-0.31 \mathrm{mh}$ \\
\hline $\mathrm{L}_{\text {end turns }}$ & $0.093 \mathrm{mh}$ & & \\
\hline
\end{tabular}

Table 12. Analytical results

\begin{tabular}{|c|c|c|c|c|c|c|c|}
\hline $\mathrm{N}, \mathrm{rpm}$ & $\begin{array}{c}\mathrm{P}_{\text {shaft, }} \\
\mathrm{kW}\end{array}$ & $\begin{array}{c}\mathrm{I}_{\mathrm{q}}, \mathrm{rms} \\
\text { Amps }\end{array}$ & $\begin{array}{c}\mathrm{I}_{\mathrm{d}}, \mathrm{rms} \\
\text { Amps }\end{array}$ & $\begin{array}{c}\mathrm{I}, \mathrm{rms} \\
\text { Amps }\end{array}$ & $\begin{array}{c}\mathrm{V}_{\text {phase, }} \\
\text { rms volts }\end{array}$ & $\begin{array}{c}\mathrm{E}_{\text {back-emf, }} \\
\text { peak line- } \\
\text { to-line }\end{array}$ & $\begin{array}{c}\text { Peak } \\
\text { efficiency, } \\
\text { percent }\end{array}$ \\
\hline 2000 & 30 & 251 & 0 & 251 & 101 & 97 & 96.5 \\
\hline 4000 & 30 & 127 & -107.3 & 166 & 94.3 & 194.6 & 97.5 \\
\hline 6000 & 30 & 86 & -107 & 137 & 95 & 292 & 96.8 \\
\hline 8000 & 30 & 66 & -106.8 & 125 & 97 & 389 & 95.5 \\
\hline 10000 & 30 & 53.4 & -107 & 120 & 99 & 487 & 93.8 \\
\hline
\end{tabular}

Table 13. Losses

\begin{tabular}{|c|c|c|c|}
\hline $\mathrm{N}, \mathrm{rpm}$ & $\mathrm{P}_{\text {Copper }}, \mathrm{W}$ & $\mathrm{P}_{\text {core }}, \mathrm{W}$ & $\mathrm{P}_{\text {magnet }}, \mathrm{W}$ \\
\hline 2000 & 965 & 111 & 2.8 \\
\hline 4000 & 422 & 335 & 11 \\
\hline 6000 & 287 & 673 & 25 \\
\hline 8000 & 239 & 1125 & 45 \\
\hline 10000 & 221 & 1691 & 70 \\
\hline
\end{tabular}

From the SPEED program the fundamental flux due to the magnet is $1.462 \mathrm{mWb}$. Lawler [18] shows that the optimum $L_{d}$ was

$$
L_{d}=\frac{3 E^{2}}{\omega_{e} P_{r}} \mathrm{~h}
$$

From Table 12, the 10-pole motor at $2000 \mathrm{rpm}$ has the following characteristics, $\mathrm{E}=39.72 \mathrm{~V}_{\mathrm{rms}} /$ phase, $\omega_{\mathrm{e}}=1046.7 \mathrm{rad} / \mathrm{s}$, and $\mathrm{P}_{\mathrm{r}}=30 \mathrm{~kW}$. From these values, the optimal inductance is

$$
L_{d}=0.1507 \mathrm{mh}
$$

From [14]

$$
\psi_{m 1}=\frac{k_{w 1} N_{p h} \phi_{m 1}}{\sqrt{2}}=\frac{0.933(40) 0.001462}{\sqrt{2}}=38.6 \mathrm{mWb}
$$

From Eq. (16) the characteristic current would be 


$$
I_{c h}=\frac{\psi_{m 1}}{L_{d}}=\frac{0.0386}{0.0001507}=256 \text { RMS Amps ; }
$$

however, as seen in Table 11 the actual inductance is $0.299 \mathrm{mh}$, which is more than necessary. Even so, the goal of $30 \mathrm{~kW}$ over the speed range from 2,000 to $10,000 \mathrm{rpm}$ is met as shown in Table 12. The problem is in attaining $55 \mathrm{~kW}$ at $2,000 \mathrm{rpm}$. This will be addressed in the next phase of research. 


\section{CONCLUSIONS}

The biggest contributor to the phase inductance is the slot inductance. This places a premium on the design of the slot-opening configuration and must be considered further. The slots are long and slender and are not necessarily the optimal design. This could pose problems in forming the laminations.

The results of the losses in the magnet seem low. Next year's research will explore calculation of magnet and core losses.

The higher fill factor of the concentrated winding allows a more compact motor, which leads to higher power density and higher specific power.

For the 6-kW motor with soft magnetic material with a lower remanence requiring larger thicker magnets, values from the two-dimensional Zhu method of calculating back-emf compare more favorably with experimental data than values from the one-dimensional method.

The 6-kW motor analyzed with SPEED software was also modeled with a per-phase equivalent circuit. The two analyses compared well with the experimental University of Wisconsin results.

The affect of stator slotting on permeance of the 6-kW motor has been calculated and compares well with the University of Wisconsin calculations.

Desirable industrial specifications in Appendix B.3, which point out that an advanced cooling technique is a major requirement for this motor, call for $55 \mathrm{~kW}$ for 18 seconds at $2000 \mathrm{rpm}$. By extrapolating data from Table 12, we see that this amount of power will require

$$
251 A^{r m s} \times 55 \mathrm{~kW} / 30 \mathrm{~kW}=460 \mathrm{~A}^{r m s}
$$

and

$$
101 V^{r m s} \times \sqrt{3} / 0.78=224 V_{\text {bus voltage }}^{r m s} .
$$

The current and bus voltage exceed the maximum specifications, which are $400 \mathrm{~A}$ and $200 \mathrm{~V}$. Design changes to eliminate this problem will be explored in the next phase of this study.

The greater than $93 \%$ efficiency requirement for $20 \%$ rated torque at speeds from $2000 \mathrm{rpm}$ to $10,000 \mathrm{rpm}$ (Appendix B.3) could be difficult to attain. This will place a premium on the type and thickness of the laminations. 


\section{APPENDIX A: \\ USEFUL MATLAB PROGRAMS}

\section{A.1 ZHU METHOD FOR CALCULATING BACK-EMF AND ITS HARMONIC CONTENT}

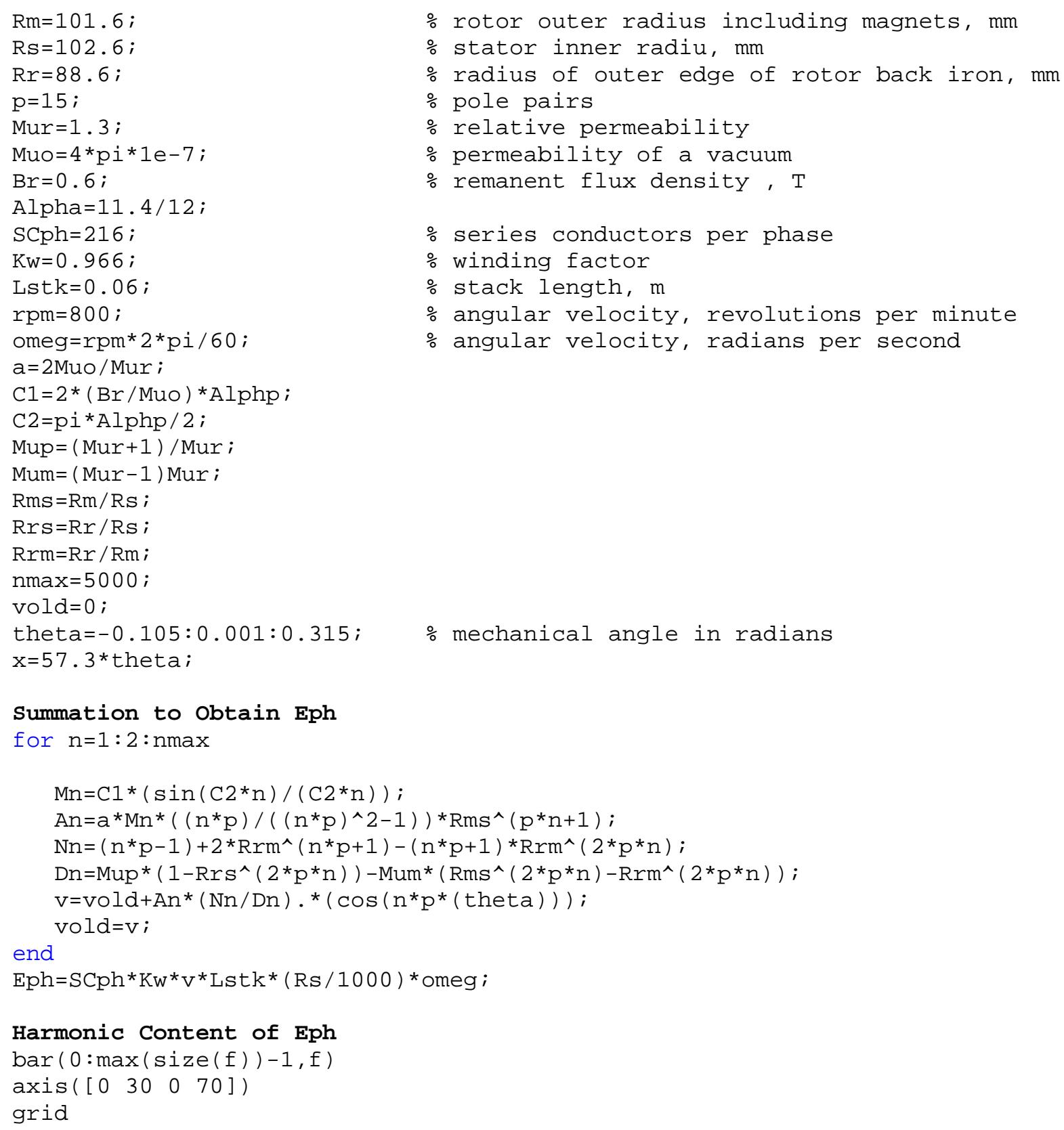




\section{A.2. CALCULATIONS OF THE PERMEANCE FUNCTIONS}

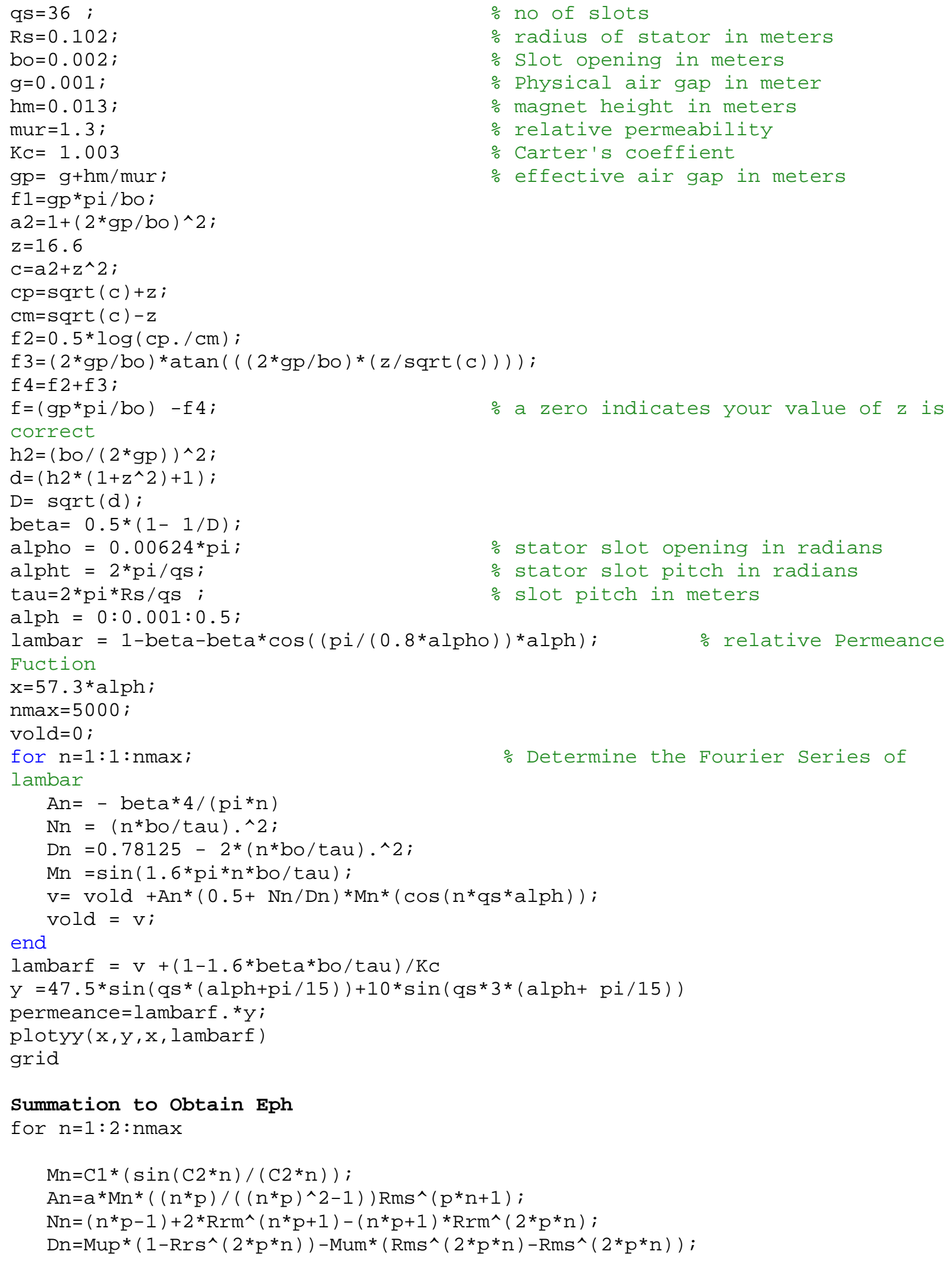


$\mathrm{v}=\operatorname{vold}+A n^{*}(\mathrm{Nn} / \mathrm{Dn}) .{ }^{*}\left(\cos \left(\mathrm{n}^{*} \mathrm{p}^{*}(\right.\right.$ theta $\left.\left.)\right)\right)$; vold $=v$;

end

$\mathrm{Eph}=\mathrm{SCph}{ }^{*} \mathrm{KW}^{*} \mathrm{~V}^{*}{ }^{*}$ stk ${ }^{*}(\mathrm{Rs} / 1000){ }^{*}$ omeg ;

Harmonic Content of Eph

$\operatorname{bar}(\theta: \max (\operatorname{size}(f))-1, f)$

$\operatorname{axis}\left(\left[\begin{array}{llll}0 & 30 & 0 & 70\end{array}\right]\right)$

grid 
APPENDIX B:

FCVT SPECIFICATIONS

\section{B.1 FCVT PERFORMANCE GOALS AND TARGETS FOR A 2010 ELECTRIC PROPULSION SYSTEM}

\begin{tabular}{|l|c|}
\hline \multicolumn{2}{|c|}{ FCVT Goals } \\
\hline Peak power & $55 \mathrm{~kW}$ for 18 seconds \\
\hline Continuous power & $30 \mathrm{~kW}$ \\
\hline Lifetime & $>15$ years or 150,000 miles \\
\hline Cost & $<\$ 12 /$ peak $\mathrm{kW}(<\$ 660)$ \\
\hline \multicolumn{2}{|c|}{ FCVT Technical Targets } \\
\hline Peak power to weight ratio & $>1.2 \mathrm{~kW} / \mathrm{kg}(<46 \mathrm{~kg})$ \\
\hline Peak power to volume ratio & $>3.5 \mathrm{~kW} /$ liter $(<16$ liters $)$ \\
\hline Efficiency (10 to $100 \%$ speed at $20 \%$ rated torque $)$ & $>90 \%$ \\
\hline
\end{tabular}

\section{B.2. FCVT TECHNICAL TARGETS FOR POWER ELECTRONICS AND ELECTRIC MACHINES (INCLUDES ACTIVE MATERIALS, MOTOR GEARS, AND HOUSING)}

\begin{tabular}{|l|c|}
\hline Power electronics (inverter and controller) & 2010 target \\
\hline Peak power to weight ratio $(\mathrm{kW} / \mathrm{kg})$ & $>12$ \\
\hline Peak power to volume ratio $(\mathrm{kW} / \mathrm{liter})$ & $>12$ \\
\hline Cost/peak power $(\$ / \mathrm{kW})$ & $<5$ \\
\hline Efficiency $(\%)$ & 97 \\
\hline Coolant inlet temperature $\left({ }^{\circ} \mathrm{C}\right)$ & 105 \\
\hline Lifetime $($ years $)$ & 15 \\
\hline \multicolumn{1}{|c|}{ Traction motor } & $\mathbf{2 0 1 0}$ target \\
\hline Peak power to weight ratio $(\mathrm{kW} / \mathrm{kg})$ & $>1.3$ \\
\hline Peak power to volume ratio $(\mathrm{kW} / \mathrm{liter})$ & $>5$ \\
\hline Cost/peak* $(\$ / \mathrm{kW})$ & $<7$ \\
\hline Efficiency $(\%)$ & $>93 @ 10 \%$ to $100 \%$ of max. speed \\
\hline Nominal voltage $($ volts $)$ & 325 \\
\hline Maximum current $\left(\mathrm{A}{ }_{\text {rms }}\right)$ & 400 \\
\hline
\end{tabular}




\section{B.3 ADVANCED TRACTION MOTOR SPECIFICATIONS}

These specifications were sent to industry in 2005 with a request for proposal to provide motors that could meet their requirements. They are desirable industrial specifications.

\begin{tabular}{|c|c|}
\hline Requirement & $\begin{array}{c}\text { Target } \\
\text { specification }\end{array}$ \\
\hline Minimum top speed (rpm) (see note 2) & 10,000 \\
\hline $\begin{array}{l}\text { Peak power at } 20 \% \text { of maximum speed for } 18 \text { seconds and nominal voltage } \\
(\mathrm{kW})\end{array}$ & 55 \\
\hline $\begin{array}{l}\text { Continuous power at } 20 \% \text { to } 100 \% \text { of maximum speed and nominal voltage } \\
(\mathrm{kW}) \text { (see note } 1 \text { ) }\end{array}$ & 30 \\
\hline Battery operating voltage ( $\mathrm{Vdc})$ & $\begin{array}{c}\text { Nominal: } 325 \\
\text { range: } 200 \text { to } \\
450\end{array}$ \\
\hline Maximum current at motor $\left(\mathrm{A}_{\mathrm{rms}}\right)$ & 400 \\
\hline Characteristic current $\left(\psi_{\text {mag }} / \mathrm{L}_{\mathrm{d}}\right)(\mathrm{A})($ see note 2$)$ & $\begin{array}{l}<\text { Maximum } \\
\text { current }\end{array}$ \\
\hline $\begin{array}{l}\text { Efficiency at } 10 \text { to } 100 \% \text { of maximum speed for } 20 \% \text { of rated torque (final } \\
\text { check: may use FTP- } 75 \text { or equivalent drive cycle) }\end{array}$ & $>93$ \\
\hline $\begin{array}{l}\text { Back-emf at } 100 \% \text { of maximum speed, peak line-to-line voltage (V) (see } \\
\text { note 3) }\end{array}$ & $<600$ \\
\hline Torque pulsations - not to exceed at any speed, percent of peak torque (\%) & $<5$ \\
\hline Peak power to weight ratio for active materials (see note 4$)$ only $(\mathrm{kW} / \mathrm{kg})$ & $>2.75$ \\
\hline Peak power to volume ratio for active materials (see note 4 ) only (kW/liter) & $>12.5$ \\
\hline Life (years) & $>15$ \\
\hline Motor cost of active materials at peak power $(\$ / \mathrm{kW})$ & $<3.2$ \\
\hline Ambient (outside container) operating temperature $\left({ }^{\circ} \mathrm{C}\right)$ & -40 to +105 \\
\hline Storage temperature $\left({ }^{\circ} \mathrm{C}\right)$ & -50 to +125 \\
\hline Coolant inlet temperature $\left({ }^{\circ} \mathrm{C}\right)$ & 105 \\
\hline Maximum coolant flow rate (liters/min) & 10 \\
\hline Maximum coolant pressure drop (psi) & 2 \\
\hline Maximum coolant inlet pressure (psi) & 20 \\
\hline Minimum isolation impedance - terminal to ground ( $\mathrm{M}$ ohm) & 1 \\
\hline Minimum insulation impedance - terminal to ground (M ohm) & 20 \\
\hline
\end{tabular}

Table notes: (1) address scalability issues in your proposal for motors rated between $20 \mathrm{~kW}$ and $70 \mathrm{~kW}$ continuous power; (2) alternative approaches will be considered if system requirements and targets are met; (3) higher values maybe considered if system requirements are met; and (4) active material consists of stator core, rotor core, stator windings, and magnets. 


\section{REFERENCES}

1. T. M. Jahns, G. B. Klieman, and T. W. Newmann, "Interior Permanent Magnet Synchronous Motors for Adjustable-Speed Drives,“ pp. 738-747 in IEEE Transactions of Industrial Applications, IA-22(4), July/August 1986.

2. O. I. Elgerd, Electric Energy Systems Theory, McGraw-Hill, New York, New York, 1971.

3. M. S. Sarma, Electric Machines, West Publishing Company, New York, New York, 1994.

4. G. Gallegos-López, F. S. Gunawan, and J. E. Walters, "Optimum Torque Control of Permanent-Magnet AC Machines in the Field-Weakened Region," IEEE Transactions on Industry Applications, 41(4), July/August 2005.

5. B. Sneyers, D. W. Novotny, and T. A. Lipo, "Field-Weakening in Buried Permanent Magnet AC Motors Drives," pp. 398-407 in IEEE Transactions, IA-21, 1985.

6. R. F. Schiferl and T. A. Lipo, "Power Capability of Salient Pole Permanent Magnet Synchronous Motor in Variable Speed Drive Applications," pp. 115-123 in IEE Transactions, IA-26, 1990.

7. W. L. Soong and T. E. J. Miller, "Field Weakening Performance of Brushless Synchronous AC Motor Drives," pp. 331-340 in IEE Proceedings of the Electronics Power Appl., 141(6), November 1994.

8. A. K. Adnanes and T. M. Undeland, "Optimum Torque Performance in PMSM Drives Above Rated Speed," pp. 169-175 in Proceedings of IEEE Industry Applications Society Annual Meeting, October 1991.

9. Liwschitz, Garik, and Whipple, Electric Machinery Vol II AC Machines, D. Von Nostrand Company, Inc., New York New York, 1946.

10. M. M. Liwschitz, "Distribution Factors and Pitch Factors of the Harmonics of FractionalSlot Windings," pp 664-666 in AIEE Transactions, 62, October 1943.

11. T. M. Jahns, Interim Report: Cost Reduction Opportunities for Permanent Magnet Synchronous Machines, Oak Ridge National Laboratory, UT-Battelle, LLC, May 24, 2004.

12. J. Cros and P. Viarouge, "Synthesis of High Performance PM Motors with Concentrated Windings," IEEE Transactions on Energy Conversion, 17(2), June 2002.

13. F. Magnussen and C. Sadarangani, "Winding Factors and Joule Losses of Permanent Magnet Machines with Concentrated Windings," pp. 333-339 in Proceedings of 2003 IEEE International Electric Machines \& Drives Conference (IEMDC), 1, Madison, Wisconsin, June 2003.

14. J. R. Hendershot, Jr. and T. J. E. Miller, Design of Brushless Permanent-Magnet Motors, Magna Physics Publishing and Clarendon Press, Oxford, 1994.

15. A. M. El-Refaie and T. M. Jahns, "Optimal Flux Weakening in Surface PM Machines using Concentrated Windings," pp. 1038-1047 in Rec. of 2004 IEEE Industry Applications Society Annual Meeting, Seattle, Washington, October 2004 (scheduled for publication in the IEEE Transactions on Industry Applications, May/June 2005).

16. Z. Q. Zhu, "Instantaneous Magnetic Field Distribution in Brushless Permanent Magnet dc Motors, Part I: Open-Circuit Field," IEEE Transactions on Magnetics, 29(1), January 1993.

17. Z. Q. Zhu and D. Howe, "Instantaneous Magnetic Field Distribution in Brushless Permanent Magnet dc Motors, Part III: Effect of Stator Slotting," IEEE Transactions on Magnetics, 29(1), January 1993. 
18. J. S. Lawler et al, "Maximum Current Magnitude Control of Surface PM Synchronous Machines During Constant Power Operation," IEEE Power Electronics Letters, 3(2), June 2005. 


\section{DISTRIBUTION}

\section{Internal}

1. D. J. Adams

2. J. M. Bailey

3. E. C. Fox

4. K. P. Gambrell

5. L. D. Marlino

\author{
5. J. W. McKeever \\ 6. M. Olszewski \\ 7. M. Starke \\ 8-9. Laboratory Records
}

\section{External}

10. T. Q. Duong, U.S. Department of Energy, EE-2G/Forrestal Building, 1000 Independence Avenue, S.W., Washington, D.C. 20585.

11. R. R. Fessler, BIZTEK Consulting, Inc., 820 Roslyn Place, Evanston, Illinois 60201-1724.

12. K. Fiegenschuh, Ford Motor Company, Scientific Research Laboratory, 2101 Village Road, MD-2247, Dearborn, Michigan 48121.

13. V. Garg, Ford Motor Company, 15050 Commerce Drive, North, Dearborn, Michigan 48120-1261.

14. E. Jih, Ford Motor Company, Scientific Research Laboratory, 2101 Village Road, MD1170, Rm. 2331, Dearborn, Michigan 48121.

15. A. Lee, Daimler Chrysler, CIMS 484-08-06, 800 Chrysler Drive, Auburn Hills, Michigan 48326-2757.

16. F. Liang, Ford Motor Company, Scientific Research Laboratory, 2101 Village Road, MD1170, Rm. 2331/SRL, Dearborn, Michigan 48121.

17. M. W. Lloyd, Energetics, Inc., 7164 Columbia Gateway Drive, Columbia, Maryland 21046.

18. Brenda Medellon, USCAR, brenda@uscar.org

19. M. Mehall, Ford Motor Company, Scientific Research Laboratory, 2101 Village Road, MD-2247, Rm. 3317, Dearborn, Michigan 48124-2053.

20. J. Rogers, Chemical and Environmental Sciences Laboratory, GM R\&D Center, 30500 Mound Road, Warren, Michigan 48090-9055.

21. S. A. Rogers, U.S. Department of Energy, EE-2G/Forrestal Building, 1000 Independence Avenue, S.W., Washington, D.C. 20585.

22. G. S. Smith, General Motors Advanced Technology Center, 3050 Lomita Boulevard, Torrance, California 90505.

23. E. J. Wall, U.S. Department of Energy, EE-2G/Forrestal Building, 1000 Independence Avenue, S.W., Washington, D.C. 20585.

24. B. Welchko, General Motors Advanced Technology Center, 3050 Lomita Boulevard, Torrance, California 90505.

25. P. G. Yoshida, U.S. Department of Energy, EE-2G/Forrestal Building, 1000 Independence Avenue, S.W., Washington, D.C. 20585. 